University of St. Thomas, Minnesota

UST Research Online

2013

\title{
Using Contract Negotiation Exercises to Develop Higher Order Thinking and Strategic Business Skills
}

\author{
Susan J. Marsnik \\ University of St. Thomas, Minnesota, sjmarsnik@stthomas.edu \\ Dale B. Thompson \\ University of St. Thomas, Minnesota, dbthompson@stthomas.edu
}

Follow this and additional works at: https://ir.stthomas.edu/ocbeblpub

Part of the Business Law, Public Responsibility, and Ethics Commons

This Article is brought to you for free and open access by the Ethics and Business Law at UST Research Online. It has been accepted for inclusion in Ethics and Business Law Faculty Publications by an authorized administrator of UST Research Online. For more information, please contact asle4660@stthomas.edu. 


\begin{tabular}{|l|l|l|l|l|}
\hline & JLSE & jlse12001 & Dispatch: May 20, 2013 & CE: N/A \\
\cline { 2 - 6 } & Journal & MSP No. & No. of pages: 48 & PE: XXXXX \\
\hline
\end{tabular}

\title{
Using Contract Negotiation Exercises to Develop Higher Order Thinking and Strategic Business Skills
}

\author{
Susan J. Marsnik* and Dale B. Thompson**
}

\section{INTRODUGTION}

This article presents two contract negotiation projects for use in Legal Environment of Business courses. Realistic simulations, such as these experiential exercises designed to provide a context for learning, are examples of problem-based learning (PBL). PBL has been characterized as "one of most important developments in contemporary higher education." By requiring students to solve problems of the kind they will encounter in the real world, problem-based exercises increase the probability that students will be able to use what they have learned after they graduate. ${ }^{2}$ Participating in these contract simulations requires students to master content in a way that alters their perception of the legal environment while developing skills they will need as citizens and businesspeople. By first negotiating a contract and then putting the agreement in writing that they understand, students learn that the real power of contract law is dynamic: it is a way to memorialize

*Associate Professor, Department of Ethics \& Business Law, Opus College of Business, University of St. Thomas

**Associate Professor, Department of Ethics \& Business Law, Opus College of Business, University of St. Thomas. The authors would like to thank participants of the 2012 Midwest Academy of Legal Studies in Business Conference, the 2012 Academy of Legal Studies in Business Conference, along with Susan Callaway, Susan, K. Snyder, and the anonymous referees for their helpful comments and suggestions. We would also like to thank our undergraduate students who have participated in contract negotiation exercises as a regular part of their education over the last decade. They have been our teachers in honing and revising these exercises. This research has been supported by grants from the Opus College of Business, University of St. Thomas.

${ }^{1}$ Marilla Svinicki \& Wilbert J. McKeachie, McKeachie's Teaching Tips: Strategies, ReSEARCh, AND Theory for College and University Teachers 208 (13th ed. 2011).

${ }^{2} I d$. at 203 .

(C) 2013 The Authors

Journal of Legal Studies Education (C) 2013 Academy of Legal Studies in Business 
the relationship they have agreed upon. Moreover, their experiences help them progress beyond memorization of legal terms and black letter law by providing them with the opportunity to analyze these concepts and to apply them in meaningful ways. Students both acquire and hone critical thinking skills in a manner that allows them to take those skills beyond the classroom experience. Furthermore, through the process of negotiating and drafting their contract, students acquire important business skills such as identifying and acquiring relevant information, developing strategies to manage risk, and learning to spot and capitalize on the benefits from collaboration and cooperation.

The authors have used contract negotiation and drafting exercises in their introductory courses for over a decade. We offer two examples of successful contract negotiation projects. The first is designed as a two-person negotiation focusing on the Uniform Commercial Code (UCC) and the second as a team-based negotiation based on the Convention on Contracts for the International Sale of Goods (CISG) ${ }^{3}$ We begin by providing a brief introduction to experiential exercises and problem-based learning that has informed the development of these exercises and then examine some of the general business lessons that derive from the use of contract negotiation exercises. We then offer our two exercises as examples. The projects demonstrate for students in a concrete way that law can be used as a tool for managing information and risk, while enabling the creation of mutual benefit. The exercises can be readily adapted to emphasize other legal concepts, according to instructional needs.

\section{Problem-Based Learning}

Students who graduate with business or professional degrees face problems in their careers for which there are no clear-cut or well-defined solutions. As a result, higher education should do more than transfer content knowledge. It should go further to develop higher order competencies. Over half a century

\footnotetext{
${ }^{3}$ At our institution, core business law courses require junior standing. The UCC exercise is designed for a Legal Environment of Business course and the CISG exercise for an International Business Law course. Both are introductory courses, and most business majors may choose between the two courses to fulfill their core business law requirements. Because of the complexities of trade finance, risk of loss, and other international issues, the international business law case is easily adaptable to a second or advanced course in international business law.
} 
ago, Benjamin Bloom analyzed and ranked classes of learning. ${ }^{4}$ In ascending order of difficulty and importance, Bloom's Taxonomy includes (1) knowledge, (2) comprehension, (3) application, (4) analysis, (5) synthesis, and (6) evaluation. ${ }^{5}$ To address the issue of providing students with the requisite skills to solve real-world problems and to move them up the taxonomy, over the last three decades, PBL approaches and curricula have been developed and used in professional schools. ${ }^{6}$ The primary goal of PBL is to prepare students to be self-directed, lifelong learners, and practical problem solvers? What makes skills-based exercises so important is that they move students beyond knowledge and comprehension of content to higher forms of learning. These methods cast students in the role of active participants who must make decisions, solve problems, and react to results. ${ }^{8}$ In addition, content learned through a realistic exercise is more likely to be learned at a deeper level and remembered and used appropriately when it is needed later. ${ }^{9}$

There is little doubt our colleagues in the academy recognize the value of teaching business and legal principles through contract drafting or

${ }^{4}$ See generally Taxonomy of Educational Objectives, The Classification of Educational Goals: book I: Cognitive Domain 18-20 (Benjamin S. Bloom et al. eds., 1956).

${ }^{5} I d$. at 18. The six stages of Bloom's taxonomy have been revised to (1) remember, (2) understand, (3) apply, (4) analyze, (5) evaluate, and (6) create. A TAxonomy for LEARNiNG, Teaching, and Assessing: A Revision of Bloom's Taxonomy of Educational Objectives 4-5 (Lorin W. Anderson et al. eds., 2001). Although the categories have changed, the basic principle of moving from content based knowledge to higher levels of cognition remains the same.

${ }^{6} P B L$ has been implemented in nursing, medical, engineering, and business schools. Howard S. Barrows, Problem-Based Learning in Medicine and Beyond: A Brief Overview, in Bringing ProblemBased Learning to Higher Education: Theory E Practice, in Bringing Problem-Based Learning to Higher Education 3,10 (LuAnn Wilkerson \& Wim H. Gijsdlaers eds., 1996) [hereinafter PBL/Higher Education]. The traditional law school case method approach is not a PBL strategy; however, law schools have also begun implementing PBL exercises into traditional courses. See Myron Moskovitz, Beyond the Case Method: It's Time to Teach with Problems, 42 J. LEGAL EDUa. 241 (1992). See also Fiona Martin, Using a Modified Problem Based Learning Approach to Motivate and Enhance Student Learning of Taxation Law, 37 Law Teacher: The InT'L. J. of Leg. EDUC. 55 (2003).

${ }^{7}$ Woei Hung, Jessica Harpole Bailey \& David H. Jonassen, Exploring the Tensions of Problem-Based Learning: Insights from Research, in Problem BASEd LeARNing IN THE INFormation AGE (Dave S. Knowlton \& David C. Sharp eds., 2003) [hereinafter PBL/Information AgE].

${ }^{8}$ SvjNicki \& McKeachie, supra note 1 , at 181.

${ }^{9}$ Id. See also Stephen D. Brookfield, The Skillful Teacher 116 (1990) (Information learned in this way is "etched much more firmly into people's perceptual filters and structures of understanding."). 
negotiation exercises. ${ }^{10}$ Contracts lend themselves to PBL in the legal environment curriculum. Not only is contract law an essential component of business law or legal environment courses, understanding contracts and contract negotiation are essential life skills. Although undergraduate students may not immediately appreciate the importance of contract law, business professionals and executives certainly do. ${ }^{11}$ Contract exercises based on the sale of goods also have practical advantages. Every student has already entered into contractual arrangements for goods, and every business will at some point procure goods. ${ }^{12}$ Additionally, contract negotiation and drafting exercises provide context for business students required to take a law course that they may think has little connection to business. The assignments provide a "real-world" flavor to the course while underscoring the importance

${ }^{10}$ See, e.g.,Marlene E. Barken, Integrating Contract and Property Fundamentals with Negotiation Skills: A Teaching Methodology, 9 J. Legal STUd. Educ. 73 (1990) (integrates contract law with property law by having students negotiate real estate purchase contracts); Susan M. Denbo, Contracts in the Classroom-Providing Undergraduate Business Students with Important "Real Life" Skills, $22 \mathrm{~J}$. LEgAL STUd. Educ. 149 (2005) (well-structured contract negotiation group project where the subject matter is to negotiate a noncompete clause for an employment contract, and the design entails groups of four students negotiating a clause, and then exchanging their clause for peer review with another group); Larry A. DiMatteo \& T. Leigh Anenson, Teaching Law and Theory Through Context: Contract Clauses in Legal Studies Education, 24 J. Legal Stud. Educ. 19 (2007) (drafting covenants not to compete and liquidated damages clauses); Bill McClendon, Debra D. Burke \& Lorrie Willey, The Art of Negotiation: What the Twenty-First Century Business Student Should Know, 27 J. Legal Stud. Educ. 227 (2010) (negotiation exercise based on endorsement contracts and morals clauses); Sharlene A. McEvoy, A Contract Writing Exercise, 14 J. Legal Stud. EDuc. 81 (1996) (two-person exercise to draft contract between returning students and parents); Mary Anne F. Nixon \& Edward M. Brayton, The Contractor's Contract: A Tool for Developing Critical Thinking Skills, 12 J. Legal STud. Educ. 220 (1994) (contractor drafting exercise); Marisa Anne Pagnattaro, From the Factory to the Playroom: Mattel, Inc.-Shenzhen Union King Sales Contract Exercise, 28 J. Legal Stud. Educ. 357 (2011) (simulation negotiation and exercise based on CISG); Margo E.K. Reder, Case Study of Apple, Inc. for Business Law Students: How Apple's Business Model Controls Digital Content Through Legal and Technological Means, 26 J. Legal STUd. Educ. 185 (case study forcusing on business and technology strategies including analysis of Apple's terms of service); Regina M. Robson, An Entrepreneurial Stand in the Business Law Corse: The Ice Cream Project 26 J. Legal Stud. Educ. 433 (2009) (negotiating and drafting procurement agreement); Judith Stilz Ogden \& Mary Ellen Benedict, What's on Your Mind? A Negotiation Role-Play, 18 J. LegaL STUD. Educ. 307 (2000) (role-playing for student groups negotiating about a labor contract covering intellectual property).

${ }^{11}$ See George J. Siedel, Commentary: Six Forces and the Legal Environment of Business: The Relative Value of Business Law Among Business School Core Courses, 37 Amer. Bus. L.J. 717, 736-37 (2000) ("In topic preference surveys of corporate executives, contract law is usually one of the top two preferred topics").

${ }^{12}$ Robson, supra note 10, at 439 (asserting that these are also areas in which business people are likely to operate without benefit of counsel). 
of studying business law as part of their business degree. Students come to recognize the essential connections between business and law, as they learn that legal tools are not only necessary to support business relationships but also can be used to solve business problems.

As the name implies, PBL is a methodology in which problems serve as the stimulus and context for student learning. ${ }^{13}$ It derives from modem cognitive psychology that suggests true learning results from the actions taken by the learner and that traditional instruction plays a role only to the extent that it fosters student-learning activities. ${ }^{14}$ In this learning environment, the teacher becomes a coach and facilitator, providing constructive feedback and direction but requiring students to seek out the answers to their questions. To ensure that the learning experience is student centered and student driven, the instructor introduces the problem early in the process of learning new content, rather than after a series of readings of assignments. ${ }^{15}$ This requires students to take responsibility for seeking out the information they need and consistently questioning what they need to know.

A well-crafted PBL exercise is "ill structured," 16 authentic, ${ }^{17}$ and collaborative. ${ }^{18}$ Business people are rarely confronted by tidy problems with neat solutions. Creativity and the ability to conceptualize new strategies are among the most important characteristics for success in management. ${ }^{19}$ Illstructured problems address these skills. Because elements of the problem are unknown, the problems encompass the possibility of several solutions that are not confined to the boundaries of one discipline. ${ }^{20}$ To be authentic, the

\footnotetext{
${ }^{13}$ Wim H. Gijselaèrs, Connecting Problem-Based Practices with Educational Theory, in PBL/HigheR Education, supra note 6, at 13.

${ }^{14} I d$. at 17 .

${ }^{15}$ LuAnn Wilkerson \& Wim H. Gijselaers, Concluding Comments, in PBL/Higher Education, supra note 6, at 101-02.

${ }^{16} I d$.

${ }^{17}$ Renee E. Weiss, Designing Problems to Promote Higher-Order Thinking, in PBL/Information Age, supra note 7 , at 27.

${ }^{18} I d$.

${ }^{19}$ Michaela Driver, Fostering Creativity in Business Education: Developing Creative Classroom Environments To Provide Students with Critical Workplace Competencies, 77 J. Educ. Bus. 28, 28-29 (2001) ("Creativity has been identified as a critical dimension in making organizations successful today.").

${ }^{20}$ Weiss, supra note 17 , at 27 .
} 
problem should relate to the subject under study. Thus, as has been demonstrated, contract drafting and negotiation problems are appropriate for legal studies in business courses. In addition, problems relating to future plans or expected careers should be designed to require students to respond to problems as future professionals. ${ }^{21}$ Finally, the problem should be structured in such a way that its solution requires a truly collaborative and integrative effort. If the students merely have to parcel out different aspects of the problem, they will lose some of the benefits of this method. Well-crafted PBL exercises encourage collaboration and student understanding ${ }^{22}$ by requiring groups to synthesize their ideas and decisions as they work through the problem. ${ }^{23}$

Using a PBL contract negotiation exercise moves students beyond memorization of black letter law by requiring mastery of legal content. It not only requires students to master legal concepts in the context of developing negotiation and drafting skills, it requires them to hone communication, collaboration and teamwork skills. PBL exercises also encourage student initiative and creativity essential to business leadership. ${ }^{24}$ Some have suggested that in designing a contract negotiation and drafting exercise, "the key point is to keep the fact situation simple enough so that students can readily apply the concepts they have learned." ${ }^{25}$ However, based on over a decade of experience and immersion in PBL literature, the authors prefer more complex designs. Our contract projects challenge students by dropping them into the kind of complex business problems in which they will find themselves after graduation. To work their way out, they have to negotiate and draft a contract that meets not only their own strategic objectives but also satisfies the strategic needs of their counterparties. The students can and do rise to the occasion and remember the concepts and skills beyond the confines of the course. ${ }^{26}$

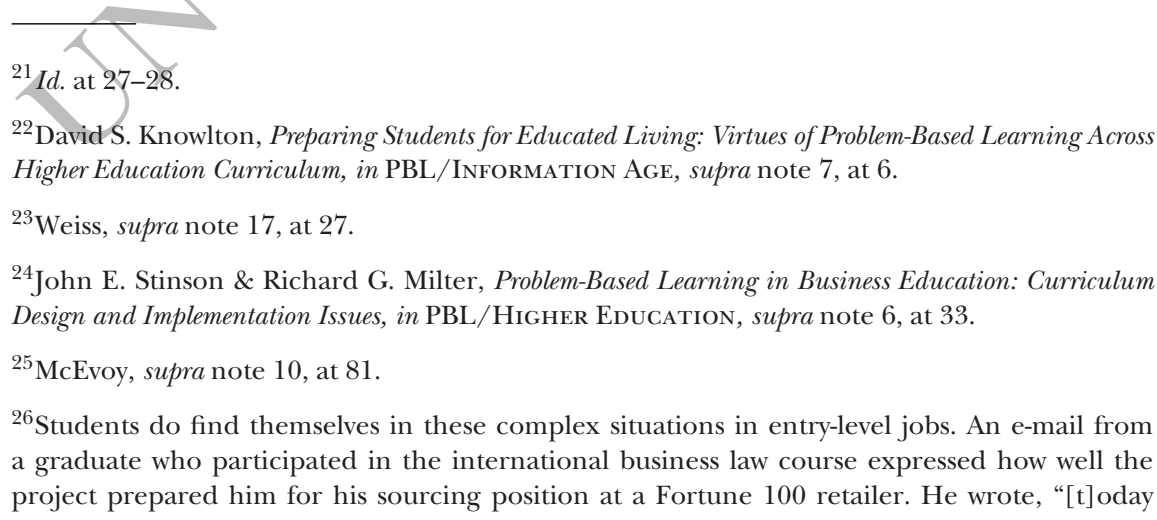




\section{Lessons for Strategic Business Decision MAKING}

Contract negotiation projects have the added benefit of helping students develop successful business strategies and skills. In addition to developing contract negotiation and drafting skills, these projects also develop a number of fundamental business management skills that students might not expect to be addressed in a law course.

Some of the most important tasks for business leaders involve managing information and risk. Through these projects, students learn that a successful contract negotiator is one who understands the importance of the information available to him or her, identifies significant information that the other side may have, and then develops a strategy for learning that information from the other side. This process of information collection can be accomplished by asking questions directly and also by implying questions through contract offers and counteroffers. Students also learn that a contract enables parties to allocate the risks associated with a transaction. This is accomplished by using specific legal terms that have certain risk allocations embedded in their definition, such as trade terms, or by modifying rules embedded in the law, like express or implied warranties or commercial impracticability. Students learn that this risk allocation may come at a cost, as the party taking more risk should demand compensation.

Students also discover that their own better understanding of legal terms may provide a competitive advantage over their trading partner. Specific legal terms may reallocate risks and burdens from one side to the other, and naïve trading partners may unwittingly agree to terms that provide the other side a significant advantage. On the other hand, students come to appreciate that cooperation can yield strategic benefits. Students learn that a successful contract negotiator does not negotiate a win at any cost competitive adyantage that may make breach more appealing than performance. Rather, a good business deal should be based on cooperation that enables both parties to benefit. Students recognize that by cooperating in a contract

alone I ... 1. Participated in [n] egotiations about liability, costing, \& transportation; 2. Reviewed INCOTERMs; 3 . Read and wrote legally binding business documents; 4 . Analyzed the legal/compliance implications of doing business in a foreign country; 5 . Communicated with overseas partners... I am realizing how amazingly prepared I feel to be taking on this type of work having studied BLAW." E-mail from May 2011 University of St. Thomas graduate, to author (Oct. 25, 2011, 4:01 CDT) (on file with author). 
setting, the two parties can "join forces" and utilize each other's "comparative advantages" 27 to jointly achieve outcomes that are better than the parties could achieve individually. Furthermore, students come to realize that in an environment where long-term relationships are important, the continued financial health of their trading partners can also become a competitive advantage over their direct competitors. As a result, students may learn that while it is important for them to bargain hard, they must still be fair, and look to capitalize on any gains from cooperation.

\section{The Contract Negotiation Problems}

We will now demonstrate how these benefits can be achieved through two specific contract negotiation projects. One is a single-class negotiation in which students are paired into buyers and sellers of batteries for personal digital music players. The other is a month-long project in which students are assigned roles of importers or exporters of a German hard cider, a highly regulated commodity. Because both exercises require some discussion of the negotiation and contract drafting process, we begin with a discussion of these common issues.

\section{A. General Negotiation Skills}

The authors set the stage for the contract negotiation with a general introduction to negotiation. A broad overview of negotiation strategies is beyond the scope of this article, however excellent resources are available to instructors who wish more detail ${ }^{28}$ or to provide students with additional readings. ${ }^{29}$

27 See David Ricardo, On the Principles of Political Economy and Taxation (1817) (explaining the theory of comparative advantage in which even countries with "absolute advantages" over other countries can still benefit from free trade with other countries by utilizing specialized production in sectors for which the trading partners have comparative advantages).

${ }^{28}$ See generally McClendon et al., supra note 10, at 280-308.

${ }^{29} \mathrm{~A}$ number of excellent articles are available for reprint from the Harvard Business School in The Harvard Business School Publishing Guide to Smart Negotiation (Harvard Business School Publishing ed., 2003), available at http://www.dophan.com/ download/HBS_Guide_Smart_Nego.pdf. See generally Walter Kiechel, The Only Four-Page Guide to Negotiating You'll Ever Need, 1 Harv. Mgmt. Update 3 (Sept. 1996), reprinted in The Harvard Business School Publishing Guide to Smart Negotiation, and James K. Sebenius, The Hidden Challenge of Cross-Border Negotiation, 80 Harv. Bus. Rev. 76 (Mar. 2002), reprinted in The Harvard Business School Publishing Guide to Smart Negotiation. 
The instructors take differing approaches to teaching the negotiation skills. The instructions for the UCC exercise more explicitly provide guidance and hints in the written instructions, while the instructor for the CISG exercise prefers to provide the guidance orally as students work through the project.

Preparation is a key skill in negotiations. In both simulations, we require students to identify their specific issues and goals, and to speculate on their negotiating partner's positions on those issues. This can be done explicitly in the instructions, as is the case in the UCC problem:

“[DO THIS BEFORE MEETING WITH YOUR PARTNER] Write down your own goals for the contract [be clear as to what legal concepts need to be addressed, and what your preferred contract term is regarding those concepts]. Also write down what you think will be your partner's concerns [i.e. how you expect the other side to want the same concepts addressed]."

And

Hint \#1: "Read the instructions carefully! It is crucial that you understand your competitive situation and the legal issues that arise due to this situation. Your job may depend upon it!" 30

While the instructions for the CISG problem are less explicit concerning preparation, over the course of the four-week negotiations, the instructor provides hints on the process. This includes a conversation with each group a few class periods after they have received the problem asking them to prioritize their business goals and to consider how the law can help them manage the risks. ${ }^{31}$ It also entails the instructor assuming the role of the negotiation teams' supervisor and reminding them their work on this project is critical to their position in the company. Later in the project, once negotiations have begun, students realize that while the importer and exporter have a shared goal in the purchase and sale of the product that their individual instructions provide for differing goals and details such as minimum orders and packaging. ${ }^{32}$ At this point, the instructor provides guidance on how to prioritize

\footnotetext{
${ }^{30}$ See infra Appendix A.

${ }^{31}$ Students are required to turn in this work as part of their individual work for the project. See infra Appendix B.

${ }^{32}$ As an example, the seller's instructions provide: "Fuchsrot sells their award winning Apfelwein to wholesalers and distributors in Europe and South America in cases containing twelve, $750 \mathrm{ml}$ bottles. Typically, Fuchsrot typically requires minimum orders of 2,000 cases." See infra
} 
their goals so that they can make decisions concerning which goals are less important and can be used as bargaining chips.

The exercises illustrate that a central negotiation skill is the extraction of information from the other business. ${ }^{33}$ More information about the other side can be helpful from both competitive and cooperative perspectives. Knowing the other side's bottom line or outside options can proyide a dominant negotiation position (i.e., getting as big of a piece of the pie as possible). At other times, knowledge of the other side's alternatives can also enable achievement of gains from cooperation (i.e., making the "pie" as big as possible) ${ }^{34}$ Students get the opportunity to learn how to extract information from their negotiation partner, through a carefully orchestrated dance of questions, offers, and counteroffers.

Negotiation of price is an important consideration for the profitability of buyers and sellers in both projects and illustrates how extracting information from the other side combined with prioritizing goals interact. In the UCC example, students are required to run the numbers on a hypothetical proposed starting price and consider issues such as whether they or their partner will pay for shipping or consumer damages. Calculating price in the CISG exercise is a bit more complex and students often prepare Excel spreadsheets factoring in different components, including tariffs, excise taxes, and the cost of letters of credit. The students know early in the process that they must select which of the Incoterms ${ }^{35}$ are most beneficial to their risk position. As work and negotiations progress, buyers will learn more about their needs and the needs of the seller, and vice versa. Each side begins to reconsider their Incoterm choices in the context of their price and payment terms.

Appendix B. The buyer's instructions set up a tension by requiring a smaller initial order than the seller's minimum: "After doing your research, you believe that the maximum initial order should be five hundred cases, each case containing twelve, $750 \mathrm{ml}$ bottles of the product. This is the preliminary shipment needed to promote the goods and to see how well Fuchsrot can perform." See id.

${ }^{33}$ Assignment \#2 further states, "Write down some questions you may want to ask your partner. (To successfully negotiate, you need to learn much about the other side. Teasing out this information through questions, offers, and proposals is part of the art of negotiation. More knowledge about the other side will help you both strategically and cooperatively: remember, you may want to cooperate to increase profits!)." See infra Appendix A.

${ }^{34}$ For examples of this, see the discussion of shipping costs and efficient breach in infra text accompanying notes $44-45$ and 55 .

${ }^{35}$ INT'L CHAMBER OF COMMERCE, INCOTERMS ${ }^{\circledR} 2010$ : ICC RULES FOR THE USE OF DOMESTIC AND International Trade Terms 2010, Pub. No. 715 (2010) [hereinafter Incoterms]. 
The team may agree to an Incoterm less favorable in terms of risk of loss in exchange for a more advantageous price, a better payment term or a more generous royalty.

A final negotiation skill taught is the importance of leaving price for the end of the negotiation. Students are told that they should wait to negotiate the final price. ${ }^{36}$ Students learn that individual components of a negotiated contract will shift burdens and risks from one party to another. These reallocations should benefit the parties collectively, but the party taking on additional burdens can and should demand compensation for these burdens. As a result, it will be necessary to negotiate the price only after these other issues are agreed upon.

In both the UCC and CISG exercises, students come to understand the importance of preparation and balanced compromise in the negotiation process when the instructor reveals the final negotiated outcomes for all of the teams. ${ }^{37}$ At this point, students realize that their preparation and performance on this contract could have either saved or cost them their job.

\section{B. General Drafting Skills}

In this project, students learn the need for clarity and comprehension in drafting contracts. Clarity reduces the chances that a contract will be misinterpreted or contain contradictory language. Clarity is enhanced by using specific headings and specific legal terms. Contracts can sometimes discuss a particular legal topic at different places in the contract. When that happens, it is possible for the different discussions to contradict each other. Using a specific heading will help readers of the contract identify the relevant language for a particular legal issue. Also though, by including all discussion about a particular topic in the same place, use of headings will possibly force contract drafters to recognize and resolve contradictions.

Furthermore, students also learn the need to use specific legal terms, as long as they themselves properly understand them. If students wish a court to interpret the contract in one particular way, using specific legal terms that

\footnotetext{
36 "I strongly recommend you to save the negotiation over the price of the batteries for later: you should first work out other terms of your agreement, because these terms will have an impact over what each side will consider a "fair price." See infra Appendix A. In the CISG problem, this is done in a coaching environment in which the instructors asks the student whether they are ready to negotiate on price and which factors need to be settled before that is possible.

${ }^{37}$ See infra text accompanying notes 59 and 76.
} 
have been completely vetted by the courts will lead to a clearly identifiably interpretation. For example, if the students agree that the buyer should pay for shipping and bear the risk of loss, the easiest way to ensure that a court will interpret the contract in this manner is to specifically label the contract a Shipment Contract or to choose the appropriate Incoterm.

On the other hand, this project also tries to remind students that they should never agree to a contract if they themselves do not understand it. Students can easily find copies of contracts on the Internet, through their work places, or in the text itself. ${ }^{38}$ We caution students against using such contracts as templates for their work. Contract drafters will frequently copy and paste language from prior contracts. However, in doing so, the drafters may no longer understand what the contract itself is stating. To improve comprehension, both instructors offer some tips on effective contract drafting. One is to "not use 'legalese:' overly complex construction." ${ }^{39}$ Instead, students are told that they "should draft [their] contract with [their] own words, so that [they] can understand it." ${ }^{40}$ Another tip is that it sometimes "helps to read the contract aloud to ensure that both you and your partner understand it." 41

\section{Two-Person Negotiation in the Legal Environment of Business Class}

This project is designed for a Legal Environment of Business course. Article II of the UCC provides the legal foundation for the purchase and sale of a large quantity of lithium batteries by an electronics company for use in a new audio-file player, competing with Apple's iPod. It was designed for use in a Legal Environment of Business course. Students are given instructions corresponding with their role as buyers or sellers. Each side's instructions include information about their own cost and revenue expectations, and indicate certain circumstances for concern. Students are then expected to identify the significant legal issues for negotiation and e-mail the instructor with their list. This enables the instructor to provide early feedback for

\footnotetext{
${ }^{38}$ Frank B. Cross \& Roger LeRoy Miller, The Legal Environment of Business, 264-67 (8th ed. 2012).

${ }^{39}$ See infra Appendix A.

${ }^{40} I d .$.

${ }^{41} I d$.
} 
students. Students then meet with their partners to negotiate the essential terms and then work together on drafting and executing a final contract. In the end, students turn in the final executed contract, along with commentaries on their partners and on their assessment of how the contract met their own individual objectives.

One of the complications introduced in this project was that, depending upon the type of manufacturing process used, these batteries might later catch fire or explode. ${ }^{42}$ Another complication was the possibility of a crippling strike at one of the seller's facilities. ${ }^{43}$ While the authors see these complications, built into the problem at the outset, as necessary components adding to the realism of the problem, instructors wishing to simplify the exercise are free to eliminate them.

This project gives students opportunities to improve their general negotiation and drafting skills. Through it, students also learn that a welldeveloped understanding of legal concepts along with a skillful application of them can generate significant strategic advantages for businesses.

\section{A. Strategic Insights: Benefits from Understanding and Using Specific Legal Terms}

This project demonstrates how knowledge of the law can have strategic benefits. One of the issues for this project is how to handle the shipping of the batteries. Under the UCG, the two main classifications of shipping are shipment contracts and destination contracts. Destination contracts are generally specified by the use of specific technical language, such as "F.O.B. [free on board] Buyer's Warehouse." Designation of the type of contract also implies allocation of both the cost of shipping and risk of loss. Consequently, better understanding of these legal terms can give a strategic advantage to one negotiation partner over the other. A savvy buyer may request that the shipment

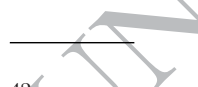

${ }^{42}$ When this project was initially designed, it was based upon speculation, drawing upon similar reports from lithium batteries in laptops. However, in November 2011, Apple announced a recall of certain iPods because "the battery in the iPod nano (1st generation) may overheat and pose a safety risk... . This issue has been traced to a single battery supplier that produced batteries with a manufacturing defect." APPLE Inc., iPod nano (1st generation) Replacement Program (Nov. 11, 2011), http://www.apple.com/support/ipodnano_replacement/.

${ }^{43}$ In order to make it easier for students to remember what facility used which manufacturing process, along with their different cost levels, it was assumed that the seller's three facilities were located in different countries, each with their specific manufacturing process and cost level. See infra Appendix A. While this project did not address international business law-specific concepts, its use of these different countries to identify manufacturing facilities would enable adaptation to do so. 
terms state, "Shipment of the batteries will be F.O.B. Buyer's Warehouse." This language will imply that the seller will bear the cost of shipping and the risk of loss, but a naïve seller might nonetheless agree to this term without realizing its implications.

On the other hand, when both parties are aware of the implications of legal terms, they may then adopt a negotiation strategy to maximize their collective benefit. In this project, sellers and buyers had access to different shippers, but the buyer's shipper was twice as expensive as the seller's. ${ }^{44}$ Since the two different shippers were in essence delivering the same service, the sellers and buyers could collectively benefit themselves by using the cheaper shipper (i.e., the seller's shipper). Careful solicitation of the shipping information between the two partners ${ }^{45}$ could reveal this collective benefit and thereby enable the partners to capture benefits from cooperation by designating this contract as a "Shipment Contract" (perhaps also using the specific language "F.O.B. Seller's Warehouse.").

Another strategic insight is that the use of a legal term can substitute for the acquisition of difficult-to-aseertain information. As noted above, one of the key skills for negotiation is the extraction of information from the other side. However, sometimes it may be difficult or impossible to acquire credible information. Nonetheless, legal terms can be utilized to shift the risk pertaining to that information to the side that possesses the information. When this is done, it will be no longer necessary for the other side to obtain that information.

Students are given instructions corresponding with their role as buyers and sellers. Each side's instructions include information about their own cost and revenue expectations, and indicate certain circumstances for concern. Students are referred to a sample contract in the text ${ }^{46}$ to give them some initial clues as to how a contract might look. At the same time, students are warned that they should not just copy the contract: "However, if you simply use the contract example, you may miss one or more possible issues. There may be issues in the sample contract that are not relevant for the assignment." ${ }^{47}$

\footnotetext{
${ }^{44}$ See id.at 41 and 48.

${ }^{45}$ See supra text accompanying notes $33-34$.

${ }^{46}$ Cross \& Miller, supra note 38, at 264-67.

${ }^{47}$ See infra Appendix A.
} 
In this project, depending upon the manufacturing process used, there was either a high risk or a very low risk ${ }^{48}$ that the batteries delivered by the seller might catch fire or explode. In reality, it is difficult for a buyer to determine a seller's manufacturing process, or even to credibly believe a seller's statement that a particular manufacturing process was used. Consequently, in this project, it was assumed (and both buyers and sellers were informed of this) that "once manufactured, [the buyer] will be unable to determine which technique was used for [the] batteries. ${ }^{" 49}$ Due to this inability, without anything else ${ }^{50}$ the seller would face a strong incentive to use the worse manufacturing technique, leaving the buyer with the risk of significant liability from future accidents.

However, by demanding something as simple as a warranty from the seller, ${ }^{51}$ buyers could create a perfect incentive ${ }^{52}$ that would force the seller to use the better manufacturing technique and thereby drastically reduce the possibility of an accident. ${ }^{53}$ As a result, the requirement of a warranty would eliminate the need for the buyer to determine the seller's technique. This project therefore demonstrates how the risk-shifting effects of specific legal terms can be used to impose liability on the side that has the relevant information, in cases where acquisition of that information by the other side is extremely problematic or costly.

\section{B. Strategic Insights: Gains from Cooperation Through the Use of Liquidated}

Damages

A final complication in this project was that there was a possibility of a debilitating future strike at the seller's best-technology-and-lower-cost

\footnotetext{
${ }^{48}$ For simplicity, the instructions indicated that there would be zero risk of accident if the better manufacturing process was used. See id.

49 See infor Appenctis

${ }^{49}$ See infra Appendix A.

${ }^{50}$ The assumption here is that the seller faced no liability after the sale.

${ }^{51}$ An alternative to demanding a warranty would be to prevent the seller from disclaiming implied warranties.

${ }^{52}$ Under the assumptions of the instructions, if sellers face no liability, then they will profit more from using the lower-cost-but-less-safe manufacturing technique. However, if sellers face full liability, their potential liability from using the less-safe technique would outweigh their manufacturing cost savings, and hence, a profit-maximizing seller will use the better technique.

${ }^{53}$ In this case, again under the assumptions of the instructions, it would eliminate the possibility of any accident.
} 
facility located in China. If this strike occurred, ${ }^{54}$ the seller could still perform but would have to utilize a much-higher cost facility in the United States. Meanwhile, the buyer has access to an alternate supplier located in Canada. By design, this alternate supplier can deliver the batteries at a cost lower than the seller's facility in the United States but twice as expensive as the seller's facility in China. Consequently, the occasion of a strike at the Chinese facility would lead to an instance where it would be efficient for the seller to breach the contract: in that case, it would be more efficient to have the batteries produced by the alternative source's Canadian facility, rather than the seller's American one. This however begs the question of how the original contract can be drafted to enable this "efficient breach." ${ }^{55}$

The questions of defining what constitutes breach and identifying preferred remedies in the case of breach are issues that should be addressed in many contracts. In this case, the definition of breach is fairly straightforward: the failure to deliver the batteries by a certain date. However, identifying an appropriate remedy that will enable efficient breach is more difficult.

One remedy that will enable efficient breach is a liquidated damages clause. Liquidated damage clauses specify a level of damages in the place of compensatory damages that may otherwise be available. In essence, liquidated damage clauses aet as an insurance policy that spreads the risks (or benefits) of a subsequent external event between the buyer and seller. ${ }^{56}$ Liquidated damages clauses is an advanced topic that is not necessarily covered in all introductory business law courses and is certainly not one that students would think of on their own. While the design of PBL projects frequently incorporates elements requiring students to conduct their own research, this is a topic that is specifically covered in class. It was presented after the negotiation assignment was distributed. At the time the topic is introduced in class, students wondering about how to solve the dilemma of a strike realize that sometimes the law develops specific technical concepts, like a liquidated

\footnotetext{
${ }^{54}$ For simplicity, it was assumed that there was a simple 10 percent chance (a fact known to both buyer and seller) of a strike. See infra Appendix A.

${ }^{55}$ See A. Mitchell Polinsky, An Introduction to Law and Economics 31-34 (2nd ed. 1989) (giving a numerical example of a case of "efficient breach").

${ }^{56} I d$. at $63-64$.
} 
damages clause, that enables businesspeople to address a complex business situation. In this case, the liquidated damage clause can reallocate the risk of the strike that would otherwise be borne solely by the seller. There are social benefits from sharing this risk with the buyer, and the buyer should be able to extract a lower overall price from the seller as compensation for bearing some of this risk.

Despite the beneficial effects of liquidated damage clauses, many courts are hesitant to enforce them. ${ }^{57}$ In general, in order for them to be enforceable, a court must find that (1) it must be the case where actual damages are difficult to estimate prospectively and that (2) the specified liquidated damages are a reasonable approximation of actual damages ${ }^{58}$ Careful drafters can address these concerns through the use of language in the liquidated damage clause itself. In discussing liquidated damage clauses in class, the instructor provides a sample clause that does this, and students can use this sample clause as a reference for their own contract. In doing so, they have to be careful in walking the line between using their own words for comprehension purposes, while also still using the specific legal terms to prevent misinterpretation of the clause by the court.

Overall, the strike possibility in this project presents significant challenges to students. The need to draft the contract to address uncertain future contingencies greatly increases the complexity of the assignment. And drafting an appropriate liquidated damage clause that will be both comprehensible and enforceable is difficult.

Nevertheless, there are some significant educational benefits from including this ill-structured component in this project. One is that the added complexity provides a dose of "real-world" conditions in an exercise in which a number of other simplifying assumptions have already otherwise been made. Student interest in projects is greatly enhanced when the projects are perceived as being more applicable to their future careers, and by facing these complexities now, students may be better prepared to deal with other complexities they encounter as future business leaders. Furthermore, by making changes to how the project is explained to students, instructors can better facilitate students' understanding of these circumstances. For example, based on student feedback, the instructor added separate question-and-answer

\footnotetext{
${ }^{57}$ See id. at 64 n.36.

${ }^{58}$ Restatement (Second) of Contracts § 356(1) (1981).
} 
sessions with all sellers in one group and all buyers in another group. These sessions enabled sellers to help other sellers better understand what their part of the project was about (and likewise for buyers).

Students also come to see the benefits from cooperation between trading partners. As noted above, a key lesson about negotiation is that cooperation can yield strategic benefits for both, when cooperation enables them to take advantage of the full resources and options available to them jointly. In this case, if there is a strike at the Chinese facility, then the batteries could be produced at either the seller's American facility or the buyer's alternative source's Canadian facility. In the event of a strike, the seller must make the decision as to whether to fulfill the contract by using the American facility or to breach the contract. Without a liquidated damages clause, the seller will face uncertainty as to the amount of damages that he or she may face due to breach. As a result, the seller may décide that the risk of significant damages is too high and may then decide to produce at the American facility. However, this is an inefficient choice because the alternative source's Canadian facility can produce the exact same batteries at a lower cost. In order for this result to be achieved in all instances, the seller and buyer must cooperate on designing an enforceable liquidated damages clause that will provide the proper incentive to the seller to breach the contract when such a breach is efficient. If so, in the case of a strike, the seller will always choose to breach and pay the liquidated damages, rather than expending a greater amount in trying to produce the batteries inefficiently. In the end, then, students can see that both the seller and the buyer will then achieve higher profits by cooperating and using a liquidated damages clause.

\section{Putting It All Together: Comparing Individual and Joint Profits Across Teams}

One of the best ways to reinforce many of these lessons is to collect all of the relevant data from each team's contract and then show the entire class each team's performance in terms of profits under the contract. ${ }^{59}$ Below are the results from the most recent implementation of this project:

\footnotetext{
${ }^{59}$ This instructor presents the compiled data when the projects are returned to students.
} 


\begin{tabular}{|c|c|c|c|c|c|c|c|c|c|c|}
\hline \multirow[b]{3}{*}{ Team } & \multirow[b]{3}{*}{ Shipping } & \multicolumn{3}{|c|}{ No Strike } & \multicolumn{3}{|l|}{ Strike } & \multicolumn{3}{|c|}{ Overall } \\
\hline & & \multicolumn{3}{|c|}{$\begin{array}{l}\text { PROFIT } \\
\text { (in } \$ 1000 \text { s) FOR }\end{array}$} & \multicolumn{3}{|c|}{$\begin{array}{l}\text { PROFIT } \\
\text { (in } \$ 1000 \text { s) FOR }\end{array}$} & \multicolumn{3}{|c|}{$\begin{array}{l}\text { Expected } \\
\text { Profit (in } \$ 1000 \text { s) }\end{array}$} \\
\hline & & Buyer & Seller & Joint & Buyer & Seller & $\overline{\text { Joint }}$ & Buyer & Seller & Joint \\
\hline A & $\$ 50$ & $\$ 1,000$ & $\$ 150$ & $\$ 1,150$ & $\$ 1,040$ & $(\$ 640)$ & $\$ 400$ & $\$ 1,004$ & $\$ 71$ & $\$ 1,075$ \\
\hline B & $\$ 100$ & $\$ 600$ & $\$ 500$ & $\$ 1,100$ & $\$ 550$ & $(\$ 150)$ & $\$ 400$ & $\$ 595$ & $\$ 435$ & $\$ 1,030$ \\
\hline C & $\$ 50$ & $\$ 550$ & $\$ 600$ & $\$ 1,150$ & $\$ 650$ & $(\$ 250)$ & $\$ 400$ & $\$ 560$ & $\$ 515$ & $\$ 1,075$ \\
\hline $\mathrm{D}$ & $\$ 50$ & $\$ 550$ & $\$ 600$ & $\$ 1,150$ & $\$ 550$ & $(\$ 150)$ & $\$ 400$ & $\$ 550$ & $\$ 525$ & $\$ 1,075$ \\
\hline $\mathrm{E}$ & $\$ 100$ & $\$ 1,050$ & $\$ 50$ & $\$ 1,100$ & $\$ 800$ & $(\$ 400)$ & $\$ 400$ & $\$ 1,025$ & $\$ 5$ & $\$ 1,030$ \\
\hline $\mathrm{F}$ & $\$ 50$ & $\$ 600$ & $\$ 550$ & $\$ 1,150$ & $\$ 525$ & $(\$ 125)$ & $\$ 400$ & $\$ 593$ & & $\$ 1,075$ \\
\hline G & $\$ 100$ & $\$ 575$ & $\$ 525$ & $\$ 1,100$ & $\$ 500$ & $(\$ 100)$ & $\$ 400$ & $\$ 568$ & $\$ 463$ & $\$ 1,030$ \\
\hline $\mathrm{H}$ & $\$ 50$ & $\$ 550$ & $\$ 600$ & $\$ 1,150$ & $\$ 600$ & $(\$ 200)$ & $\$ 400$ & $\$ 555$ & $\$ 520$ & $\$ 1,075$ \\
\hline I & $\$ 100$ & $\$ 500$ & $\$ 600$ & $\$ 1,100$ & $\$ 650$ & $(\$ 250)$ & $\$ 400$, & $\$ 515$ & $\$ 515$ & $\$ 1,030$ \\
\hline $\mathrm{J}$ & $\$ 50$ & $\$ 650$ & $\$ 500$ & $\$ 1,150$ & $\$ 800$ & $(\$ 400)$ & $\$ 400$ & $\$ 665$ & $\$ 410$ & $\$ 1,075$ \\
\hline K & $\$ 50$ & $\$ 950$ & $\$ 200$ & $\$ 1,150$ & $\$ 1,000$ & $(\$ 600)$ & $\$ 400$ & $\$ 955$ & $\$ 120$ & $\$ 1,075$ \\
\hline $\mathrm{L}$ & $\$ 100$ & $\$ 753$ & $\$ 348$ & $\$ 1,100$ & $\$ 1,360$ & $(\$ 960)$ & $\$ 400$ & $\$ 813$ & $\$ 217$ & $\$ 1,030$ \\
\hline M & $\$ 50$ & $\$ 175$ & $\$ 975$ & $\$ 1,150$ & $\$ 578$ & $(\$ 178)$ & $\$ 400$ & $\$ 215$ & $\$ 860$ & $\$ 1,075$ \\
\hline $\mathrm{N}$ & $\$ 50$ & $\$ 550$ & $\$ 600$ & $\$ 1,150$ & $\$ 600$ & $(\$ 200)$ & $\$ 400$ & $\$ 555$ & $\$ 520$ & $\$ 1,075$ \\
\hline $\mathrm{O}$ & $\$ 50$ & $\$ 575$ & $\$ 575$ & $\$ 1,150$ & $\$ 418$ & & $\$ 400$ & $\$ 559$ & $\$ 516$ & $\$ 1,075$ \\
\hline
\end{tabular}

There are a number of lessons that students can see from this table. In this case, all of the student teams implemented some form of a liquidated damages clause (although for some it was too high), ${ }^{60}$ without which some teams would have had lower joint profits. On the other hand, not all teams realized that they could jointly benefit by using the buyer's shipper and overspent on shipping. That mistake led to those teams having lower joint profits. Consequently, the instructor was able to point out that, comparing Team $\mathrm{F}$ with Team $\mathrm{G}$, both partners in Team $\mathrm{F}$ had higher profits than their counterparts in Team G. There was a similar comparison between Team H and Team I.

$\checkmark$ The instructor also pointed out that if this was a real-life negotiation project, some of the students might end up losing their jobs due to their poor negotiation performance, particularly if the strike occurred. Sellers in Teams A, E, and L would be particularly vulnerable, because their negotiated contract put their company at risk of significant losses in the case of a strike, without the countervailing possibility of achieving significant profits in the

\footnotetext{
${ }^{60}$ When this project was run previously, only about half of student teams used a liquidated damages clause. However, after making changes noted above to include separate buyer and seller group discussions, students seemed to better appreciate the need for a liquidated damage clause.
} 
case of no strike. In pointing this fact out, the instructor reminded the students of the absolute need for them to "run the numbers" on all possibilities, to ensure themselves that they understood the risks that their negotiations might be exposing to their companies. The instructor also reminded students that, as long as they bargain fair, it is also necessary to bargain "hard" to protect their company's interests.

\section{Student Responses}

Students both enjoyed this project and got significant educational benefits. One student wrote, "I most enjoyed the contract project. It was conducted as close to 'real life' as we could get in the classroom, and it forced us to think critically and apply legal [concepts]." A number of students noted that the reason that the contract project was what they liked most about the class was because it gave them a "Faste of the real-world!" Students also recognized the educational benefits. One wrote that "it was interesting to see how much goes into a contract," while another called it "an eye-opening experience." Another student wrote that what they liked the most was "The challenge of accurately identifying key terms and applying them to a real-life situation. The project helped me learn the terms a lot!" In the end, students felt they had achieved something by negotiating and drafting their own contract. One student wrote, "I liked the writing of the contract itself, especially because we could collaborate and hammer out the important parts together. It made the negotiations seem real and gave me a real sense of accomplishment when we finally agreed on price and terms." ${ }^{.61}$

\section{Team-Básed Negotiation in the INTERnational Business Law Class}

This project is designed for an International Business Law course. The course fulfills the core business law requirement for most majors at the authors' institution. Although most students take the course as their only business law course, a number of business concentrations recognize the course as an elective, so some students have already completed the Legal Environment of Business course. The project may be used for either a first or subsequent

\footnotetext{
${ }^{61}$ Student Evaluation Comments, University of St. Thomas, BLAW 303, Fall 2010 [available on request from the authors].
} 
business law course. The international nature of the course adds a degree of complexity and nuance not found in a traditional U.S. law course. CISG, the federal law of contracts in the United States, provides one of the legal foundations for the contract negotiation. In addition, given the international nature of the project, students must also negotiate a host of other factors including trade finance, currency risk, risk of loss or damage to goods shipped internationally, and cultural and language risks. Because of the increased complexity of the problem, students negotiate in teams of three or four buyers paired with three or four sellers. This allows the groups to parcel out subject matter expertise among the members of the groups and allows them to learn about intergroup negotiations as well as intragroup negotiations. To simulate the cross-cultural/language issues, each buyer negotiation group is paired with a seller negotiation group in a different section of the class. ${ }^{62}$ Although the exercise works with students negotiating face to face, when groups are in different sections and are allowed to negotiate only through electronic means, students learn how easy it is to misinterpret written language. ${ }^{63}$ The subject matter of the contract is Apfelwein, an apple cider beverage popular in the Frankfurt area of Germany. Both the seller and buyer are small, family fun businesses negotiating an export/import agreement. Sellers assume the role of employees of Fuchrot GmbH, a German manufacturer and exporter of spirits. Buyers act as employees of Potent Potables, Inc., an American importer and distributor of specialty European foods and beverages.

Students receive the problem before any instruction on relevant areas of contract law. ${ }^{64}$ On the first day scheduled to begin the study of international contract law, both the buyer and seller student teams receive general instructions and two pages of role specific instructions that include general information about their company, the product, and their goals for the business transaction. ${ }^{65}$ Providing the problem early is an important aspect of PBL

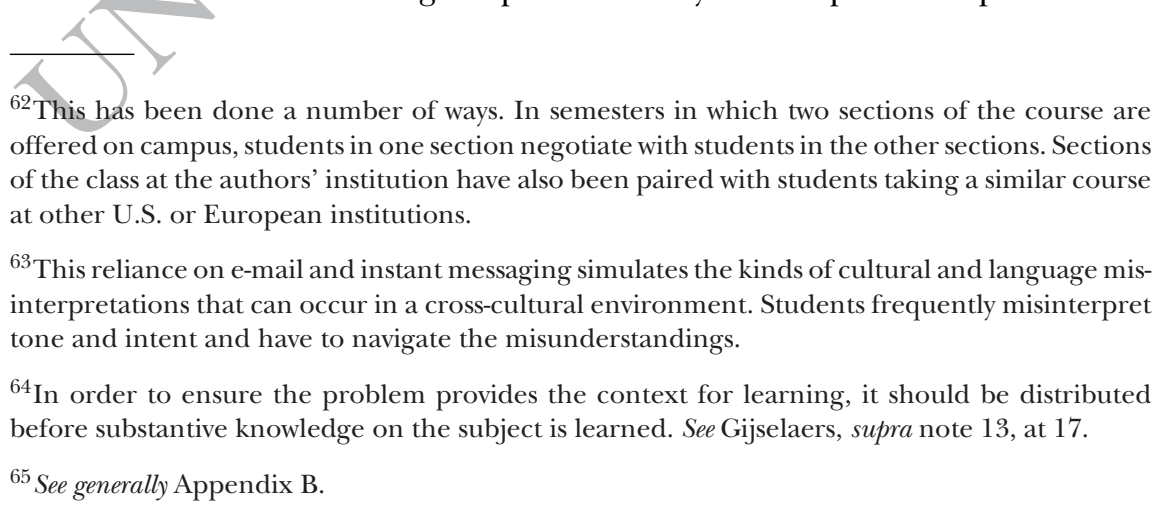

${ }^{62}$ This has been done a number of ways. In semesters in which two sections of the course are offered on campus, students in one section negotiate with students in the other sections. Sections of the class at the authors' institution have also been paired with students taking a similar course at other U.S. or European institutions.

${ }^{63}$ This reliance on e-mail and instant messaging simulates the kinds of cultural and language misinterpretations that can occur in a cross-cultural environment. Students frequently misinterpret tone and intent and have to navigate the misunderstandings.

${ }^{64}$ In order to ensure the problem provides the context for learning, it should be distributed before substantive knowledge on the subject is learned. See Gijselaers, supra note 13, at 17.

${ }^{65}$ See generally Appendix B. 
methodology, as it requires students to generate questions. Initially, the questions are fundamental such as "What does a contract look like?" or "What goes into a contract?" Over the next two to four weeks, as the problem provides the context for learning contract law, the questions become more complex. Early in the project, the students learn to work with their teammates to understand the problem and to define what they do and do not know. The instructor provides minimum background information, asks questions, and directs the students to authoritative sources of information. At the same time, each student team begins the process of getting to know the other team and begin negotiating.

The problem is also designed so that students learn how to research business-specific related legal information. The choice of importing an alcohol-based beverage is intentional. Not only are students interested in the topic, more importantly, it provides students with the opportunity to research a highly regulated product. Typically, they begin by determining that the product category is on the U.S. Harmonized Tariff Schedule (HTS). From there, they learn that there are both federal and state excise taxes that become the responsibility of the importer of record. They also learn that there are specific and detailed federal requirements for labeling alcohol imports. And, they learn how to find authoritative resources to help them learn the requirements and incorporate them into their contract.

\section{A. Strategic Insights: Benefits from Understanding and Using Specific Legal Terms}

This multiperson, team-based project also demonstrates how knowledge of the law can serve strategic benefits. As with the batteries two-person negotiation, a key issue in this project has to do with how to handle shipping. However, using international contract law changes the dynamics. The issues are different under the CISG than under the UCC As with the UCC, the default rule under the CISG if the parties fail to choose a trade term to allocate the risk of loss or damage in transit is a shipping contract. However, unlike the UCC, the CISG does not include specific trade terms. Rather, the trade terms customary in international sales contracts are those published by the International Chamber of Commerce (ICC): the Incoterms. ${ }^{66}$ Courts in a number of CISG signatory countries, including the United States, have held that the Incoterms are incorporated into the CISG through Article

${ }^{66}$ See InCOTERMS, supra note 35. 
9(2) ${ }^{67}$ Therefore, in addition to learning the default rules delineated in the CISG, students must also learn the current version of the Incoterms. The most recent iteration of the Incoterms, Incoterms 2010, entered into force in January of 2011. Unlike previous versions of the Incoterms, the eleven Incoterms are categorized according to "rules for any mode or modes of transportation" and "rules for sea and inland waterway transport." Students must determine which are for shipment contracts (all "E," "F," and "C" terms) and which designations indicate destination contracts (all "D" terms). In addition, because the problem requires containerized shipping, students must read the Incoterms to determine which are appropriate for containerized shipping and which are not. The international contract negotiation exercise requires students to learn the trade terms but also to recognize which are most advantageous for their position as importer or exporter. To reach this level of understanding, students move from a surface understanding of the terms as they practice applying them. The process of learning begins with students in their groups discussing and assessing which term or terms work to their advantage in the contract. For example, a German exporter group may propose the EXW term because it means the least amount of risk for them. When their paired buyer group receives the seller's proposal they analyze the consequences of accepting that particular trade term. In order to respond to the proposal, the buyers will be compelled to learn and really understand the practical consequences of accepting this term. The negotiation process requires the student to be responsible for their learning. This self-education bridges the law-skills dichotomy and moves the educational experience up Bloom's Taxonomy ${ }^{68}$ from memorization of knowledge to comprehension and application.

Although some of the Incoterms appear to be similar to those in the UCC, they are substantially different. For example, the example used in the previous exercise to designate a destination contract under the UCC, "F.O.B. Buyer's Warehouse," would not be allowed under the Incoterms. Students consulting the ICC guide to Incoterms discover the proper format for F.O.B. is "F.O.B. (insert named port of shipment) Incoterms ${ }^{\circledR}$ 2010." They also learn that F.O.B. may only be used if goods are shipped by ocean or inland waterway and is not appropriate when goods are shipped in containers,

\footnotetext{
${ }^{67}$ St. Paul Guardian Ins. Co. v. Neuromed Med. Sys. \& Support, Gmbh, 00-CV-9344, 2002 U.S. Dist. LEXIS 5096, at 9-10 (S.D.N.Y. Mar. 26, 2006).

${ }^{68}$ See supra text accompanying note 4 .
} 
because containerized shipments are often handed over to the carrier before they are on board the vessel. ${ }^{69}$ The Incoterm that would most closely approximate the UCC F.O.B. functioning as a destination contract would be DDP (delivery duty paid) ${ }^{70}$ Strategically, a seller might be reluctant to choose this Incoterm, since it represents both the maximum obligation for the seller, including all importing obligations in buyer's country, as well as the greatest risk in terms of loss or damage. The parties should not use this Incoterm if a foreign seller may not be able to obtain import clearance, in which case the DAP (delivered at place) Incoterm is more appropriate, since the seller has no obligation to clear the goods for import. ${ }^{71}$

In addition to paying attention to the mode of transportation, students must also be cognizant that misusing an international trade term might change their contract from a shipment contract to a destination contract. This might happen should the parties inadvertently use language appropriate for the UCC, such as "F.O.B. Buyer's Warehouse." However, once the parties understand the details of these legal terms, they understand that with three letters they can designate a host of responsibilities such as which party must obtain export licenses or other formalities for exports, which party must obtain import clearance and pay customs duties, which party makes the contract for carriage, and who is responsible for procuring insurance. Students quickly see that the required allocation of costs required for a particular Incoterm will substantially impact the price to which they agree. They also learn that the choice of a particular three-letter term also triggers legal issues such as where delivery occurs, where the risk transfers from the seller to the buyer, and when documents concerning the shipment must be provided.

Because the students are dealing with the complexities of the Incoterms, each team is provided with the same shipping data, although the amount charged may be expressed in either euros or dollars so students must also consider exchange rate risks. ${ }^{72}$ The one exception is the cost of ocean freight depending upon whether a U.S. shipping company or European shipping company is used. Students are also provided with details on the cost of insurance, destination and delivery charges, and other typical charges such as fuel

\footnotetext{
${ }^{69}$ See InCOTERMs, supra note 35 , at 87.

${ }^{70} I d$. at $69-75$.

${ }^{71} I d$. at $61-67$.

${ }^{72}$ See infra Appendix B.
} 
and security surcharges. ${ }^{73}$ This granular detail requires the students to really study the Incoterms so that they understand how the choice of Incoterm will impact the price. Students gain strategic insights into pricing and learn that they may be willing to accept an Incoterm with a greater amount of risk in exchange for payment in their own currency and a better price. Students quickly learn that working collaboratively with each side negotiating to advantage to the benefit of both parties to a long term contract.

The payment mechanism the students choose is another illustration of how risk is shifted between the parties and how the cost of shifting that risk might be allocated between the parties. Parties may choose payment on an open account (buyer's preference) or payment in advance (seller's preference). Student groups may start out with these two positions, but often compromise, choosing to use the international banking system for payment or acceptance against documents or through an irrevocable letter of credit. Both of these payment methods have risks for both the buyer and the seller, and because the buyer will bear the initial cost of balancing the risk, the buyer should negotiate a better price to accommodate the seller's great security in receiving that payment mechanism.

\section{B. Strategic Insights: Dealing with Force Majeure}

As with the UCC problem, this problem asks students to deal with issues beyond their control. The additional complication built into this exercise is the possibility that a ruling from the World Trade Organization (WTO) might allow the United States. to substantially raise tariffs on categories of European Union goods. Students understand that following the WTO ruling in the U.S.-EU Beef Hormone Dispute case, the U.S. twice imposed retaliatory tariffs of 100 percent on certain categories of food imports from the European Union. ${ }^{74}$ Students understand a 100 percent increase in tariffs would destroy any profit margin the buyer (likely the importer of record) might have and may make the contract a money-losing proposition where the only economically sound option would be for the buyer to breach the contract. However, rather than focus on the issue of efficient breach and

\footnotetext{
${ }^{73} I d$.

${ }^{74}$ See Renée Johnson \& Charles E. Hanrahan, The U.S.-EU Beef Hormone Dispute, Congressional Research Service Report for Congress (Dec. 6, 2010), available at http://www.fas.org/ $\mathrm{sgp} / \mathrm{crs} / \mathrm{row} / \mathrm{R} 40449 . p d f$ (providing details on the WTO case and an overview of 1999 and 2009 retaliatory actions).
} 
liquidated damages, this problem focuses on the circumstances under which the parties may suspend their performance without breaching the contract. The CISG's Article 79 providing an excuse for nonperformance functions much the same as the UCC's commercial impracticability rule in Section 2615. It relieves a party from its contract obligations if an unforeseen event causes extreme hardship or difficulty in performing its obligations. Unlike Section 2-615, which provides only the seller with an excuse, Article 79 is equally available to both the buyer and the seller and that a party may suspend its performance under the contract for the duration of the impediment. This would, in theory, allow the buyer to suspend its importation of Apfelwein for as long as a retaliatory tariff was in pace for imported hard cider without being in breach of contract. However, Article 79 only provides an excuse for nonperformance only if the nonperforming party can prove it was due to an impediment beyond his control and that it was not reasonably foreseeable at the time the contract was formed. Because the possibility of a tariff increase, and a host of other events that could impact either parties' ability to perform, are foreseeable, the parties are required to include a well negotiated force majeure clause.

Standard textbooks and model contracts often provide an example of a force majeure clause from pro forma invoices or sample contracts. ${ }^{75}$ Many of these are based on the UCC notion of commercial impracticability and only allow for the seller to suspend performance. Students must first determine why these clauses will not work and then provide a more balanced solution. This requires each buyer team and each seller team to determine what are the events that could happen that would make performing their contract obligations difficult or impossible. For the buyer, this would likely be a tariff increase. For the seller, it could be destruction of the German apple crop required for making Apfelwein due to weather or pestilence. A strike by the stevedores at the Hamburg docks could also impede performance for one of the parties. and which party needs to take that potentiality into account will depend upon the Incoterm selected. The groups are encouraged to think about the events that will impact their ability to perform and to include them in the force majeure clause. In addition, the teams are encouraged to think about how long performance can be suspended before the parties may avoid the contract without liability. Students are provided with access to articles on

\footnotetext{
${ }^{75}$ Richard Schaffer, Filberto Agusti, Lugien J. Dhooge \& Beverly Earle, International Business LaW ANd Its Environment 121 (8th ed. 2012).
} 
the Pace University CISG website, which provides insights into drafting these clauses. $^{76}$

Drafting a force majeure clause is difficult, but it forces students to consider the kinds of circumstances that will make it difficult to perform. Further, it requires them to truly understand where the risks are in their contract and how to plan for those contingencies.

\section{Putting It All Together: The Annotated Instructor Response and Meetings with Teams}

As with the UCC exercise, providing relevant data from the entire project to the whole class is illuminating. For the international contract negotiation, this is done in terms of the price, expressed with the Incoterm and payment mechanism. On the day the project is handed in, the instructor records the price (including currency chosen), Incoterm, payment mechanism, and quantities on the board at the front of the class. Students can see at a glance the way other teams have allocated risk of loss, currency risk, payment risk, as well as which side negotiated the most adyantageous price and quantity terms. It also provides an opportunity for students to query other teams on how they reached the result that they did and for some teams to realize that they may have missed important considerations in calculating price or allocating the risk.

In addition to the classroom discussion, the instructor reads and annotates each contract, providing students with concrete information on what the students did well, what they may have missed, and mistakes they may have made. The extensive annotation in the form of comments directly on each contract is intended to provide each team with a template of issues to consider when they negotiate their next contract. Student teams are e-mailed copies of their respective annotated contract and then meet with the professor as a team for a minimum of half an hour to debrief the contract. The combination of annotations and the meeting provides students with the opportunity to explain ambiguities in the contract and to ask and answer questions. The combination of annotation and meetings as an assessment method works particularly well in that no two contracts are the same, and often a last-minute

\footnotetext{
${ }^{76}$ See John P. McMahon, Guide for Managers and Counsel, PAcE U. L. Sch. (May 2010), http://www.cisg.law.pace.edu/cisg/guides.html; see also John P. McMahon, Drafting CISG Contracts and Documents $\mathcal{E}$ Compliance Tips for Traders, Pace U. L. ScH. (Jan. 2004), http://www.cisg.law.pace.edu/cisg/contracts.html.
} 
change in a student contract has unintended consequences for other parts of the contract. For example, student often struggle with the details of a particular Incoterm, and the combined annotations and face-to-face meeting provides an opportunity to reinforce some of the key issues concerning how a particular Incoterm impacts various parts of the contract. For example, if the students have selected one of the "F" or "C" terms but have provided for a payment mechanism in which the buyer does not pay until after the goods have been sold, the annotations and meeting help them to understand that this combination changes the meaning of the trade term from a shipment contract to a destination contract. Likewise, if the students have chosen an "F" term and require payment against documents or payment via an irrevocable letter of credit, the instructor has two opportunities to reinforce seller and buyer responsibilities under the Incoterms and why such a provision for payment would be impossible. The combination of the annotation with the discussion provides a meaningful opportunity to provide additional feedback based on the actual product that has been turned in.

\section{Conclusion}

We present two contract negotiation projects for use in introductory law courses in business curricula to demonstrate the kinds of skills students develop when placed in complex business environments, leaving it up to the students themselves to find their way out by negotiating and drafting contracts. We hope that our colleagues will find these exercises useful as presented. However, although the PBL pedagogical methodology is the same in both exercises, the instructors' approaches to the problems varied. In presenting both problems and approaches we hope to provide examples of how these problems can be modified for particular needs at other institutions and to match instructional preferences.

For example, for those teaching a UCC-based course, while we have found that the inclusion of instruction on liquidated damages clauses can enhance student understanding of how that aspect of the law can provide a strategic business advantage, if an instructor does not cover liquidated damages, that part may be omitted. Similarly, if an instructor teaching an international business law course wishes to make the problem less complex from a U.S. regulatory standpoint, another product may be selected. For example, students have also been asked to negotiate a contract for industrial-sized cans of round, red, ripe USDA inspected tomatoes from the People's Republic 
of China. Because of its international components, the UCC problem could easily be to an international business law course by adjusting the focus to the CISG and Incoterms and discussing the interplay between liquidated damages and force majeure.

Instructors may also adapt our approaches to providing hints on contract negotiation and drafting. For those wishing more explicit instructions, those available in Appendix A could be incorporated into the written instructions for the CISG exercise. For those preferring to coach students orally through the project, the hints in the UCC exercise could be eliminated.

Regardless of which approach an instructor chooses, PBL contact negotiations provide students with a rich and robust environment in which to learn. The "real-world" flavor of these projects makes them particularly appealing, and students will recognize how much better they understand the law of contracts when they put themselves into the midst of a contract. In the end, our students found negotiating their own contract "an eye-opening experience," while completing the contract gave them "a real sense of accomplishment."

These exercises provide even more than a means of teaching content and more than an enjoyable experience for students. Their design encourages the development of strategic management and higher-order thinking skills that will last beyond their course and beyond graduation. The projects offer opportunities for showing the strategic advantages from understanding the law. Better knowledge can provide a competitive advantage over a particular trading partner, while skillful application of the law can enable business leaders to achieve strategic objectives. By forcing students to consider these strategic implications, students' comprehension progresses to higher orders of understanding. Furthermore, through these projects, students will discover the value of collaboration and cooperation. While you may be competing with your trading partner over price, there are other components of a contract where cooperation can provide direct benefits to both sides. Skillful managers must learn to recognize not only competitive advantages but also cooperative ones.

It is our hope that by using these exercises, those created by our colleagues, and any new or modified contract simulations you might create, business law faculty will spur greater student interest in their courses, as students relate their both enjoyable and formative experiences in negotiating a contract in their business law course. Use of contract negotiation exercises will also enhance the common good of universities, in preparing students for their roles as future business leaders. 


\section{Appendix A: Legal Environment of Business: Contract Negotiation and Drafting Exercise}

\section{Buyer's Instructions:}

You are the head of a division of an electronics company, Honeycrisp, headquartered in YourState, and you will be releasing a new audio-file player. In order to deliver long battery life but compact size, you will utilize lithium batteries in your player. You will be meeting with the CEO of a lithium battery manufacturer, Libatt, to discuss having them supply 100,000 lithium batteries for you (one for each player). In preparation for this meeting, you have collected some important information from within your company.

Your company has determined (with absolute certainty) that you will be able to sell all of these audio players for $\$ 40$ each. With the exception of the battery costs, all other costs (including inputs, marketing, etc.) will total $\$ 20$ for each player. Consequently, you could generate a profit from your players, as long as the total cost (including any shipping charges that you pay, plus any expected damage payments that you are responsible) for all batteries is below two million dollars $(\$ 2,000,000)$.

One of the key concerns with lithium batteries is the possibility that the batteries may catch fire or explode. There have been a number of recalls for lithium batteries for laptops. In 2006, Dell, Apple, Toshiba, and Lenovo recalled lithium laptop batteries due to possible fire or explosions. ${ }^{77}$ More recently, Hewlett-Packard recalled lithium batteries in $2009 .{ }^{78}$ Lithium battery recalls have not been limited to laptop computers either. In August 2010, Apple recalled iPod nanos due to lithium batteries, because they could "overheat and prevent the iPod nano from working and deform it."79

Tracy V. Wilson, What Causes Laptop Batteries to Overheat?, How STuFf Works http:// computer.howstuffworks.com/dell-battery-fire.htm (last visited Dec. 1, 2012).

${ }^{78}$ See U.S. Consumer Product Safety Commission, HP Recalls Notebook Computer Batteries Due to Fire Hazard (Oct. 15, 2009), available at http://www.cpsc.gov/cpscpub/prerel/prhtml09/ 09221.html.

${ }^{79}$ See Darrel Etherington, Apple Acknowledges Battery Overheating in First Generation iPod Nano, Gigaom (Oct. 19, 2009, 7:53 AM), http://gigaom.com/apple/apple-acknowledges-batteryoverheating-in-first-generation-ipod-nano/ (quoting Apple Inc., http://support.apple. com/kb/TS2099). See also iPod Fingered in Car Inferno, The Register (July 10, 2009, 11:08 GMT), http://www.theregister.co.uk/2009/07/10/saab_inferno/ for a story where an iPod might have led to a fire that "torched" a Saab; see also iPod Nano in Airport Trouser Conflagration Horror, THE 
These problems are caused by small metal particles that sometimes show up in the lithium solution inside a battery cell. When heated significantly, such as during extended use of a battery, these metal particles may cut into the separator between battery cells. This causes a short circuit, which can lead to a fire or explosion. ${ }^{80}$

You face a major problem in buying these batteries from Libatt. You have heard that Libatt uses two different techniques: one essentially eliminates the risk of fire or explosion, while this risk remains for the other. Your problem is that, once manufactured, you will be unable to determine which technique was used for your batteries (the differences are within the sealed liquids, and you may not trust the external markings). Your engineers have constructed estimates of possible fires, explosions, and monetary damages that would result from these. These are included in the table below. You should consider whether you might want some sort of legal protection from Libatt when you cannot tell which technique has been used. (What legal concept would protect you in case of a fire or explosion?)

You are expecting to have a good product launch, but it is essential for the batteries to be available to you by November 15th, so that you can have the product in stores in time for the Christmas buying season (you may lose all sales if you miss this deadline [i.e., your revenues will be zero!]). You have heard that Libatt may have labor issues in China, and you have developed a good estimate of a strike occurring: a 10 percent chance (10\%). Consequently, you have investigated alternative suppliers. You have found one supplier in Canada that uses a manufacturing technique that eliminates the risk of fire, but you expect that their total price for supplying batteries $(\$ 1,600,000$, including shipping and insurance) will be higher than what you expect Libatt can offer. Nonetheless, if Libatt cannot deliver due to these labor issues (their cost may rise if they have to use secondary facilities), you might be able to turn to this Canadian company and still have the batteries ready when you need them. But, if you are forced to use this other company, you think that Libatt should pay for part, because the strike would be their fault.

REgisTer (Oct. 8, 2007, 9:44 GMT), http://www.theregister.co.uk/2007/10/08/ipod_nano_ blaze_horror/ for a story where an iPod might have caught someone's pants on fire; see also Japanese Ministry of Economy, Trade and Industry, Serious Accidents Involving Consumer Products (Aug. 19, 2008), http://www.meti.go.jp/english/press/data/nBackIssue20080819_02.html, for a story where an iPod's "battery overheated and partially scorched a tatami mat."

${ }^{80}$ See Wilson, supra note77. 
You also have information about your exclusive shipping contractor, Consolidated Express (which is the only one you are allowed to contract with). The cost for shipping 100,000 batteries without insurance will be $\$ 47,900$. There is a 2 percent chance that this shipment would be partially damaged. You have precisely calculated that this damage would cause $\$ 100,000$ worth of damage. Insurance to cover this loss (the shipping company will not pay if you do not purchase insurance from them) will cost an additional $\$ 2,100$. Libatt may use another shipper.

Furthermore, as you can probably tell, you are extremely busy and do not want to deal with the long delays and cost of litigation. You would prefer using an alternative, if any dispute arose.

Below is a table with some data provided by your company and some calculations that you should do to help in your negotiation:

\begin{tabular}{l} 
\\
\hline $\begin{array}{l}\text { Total Revenues from Audio File Players, if you produce before Christmas } \\
\text { season }\end{array}$ \\
Total Costs from all other Expenses \\
Total Profits if you have to use the Canadian supplier due to a strike [you \\
$\quad$ will not be paying Libatt, and Libatt may owe you damages, but do not \\
include Libatt's damages] \\
Expected number of overheating incidents if lesser technique used (for \\
$\quad \begin{array}{l}\text { 100,000 batteries) } \\
\text { Expected number of overheating incidents if better technique used (for }\end{array}$ \\
$\quad$ 100,000 batteries) \\
Average Expected Damages to Consumers from each Overheating Incident \\
Total Expected Damages to Consumers if Lesser Technique Used \\
Proposed Total Price for 100,000 batteries \\
Total Profits if the only costs you pay are the price for the batteries (no \\
$\quad$ shipping, insurance, damage), and there is no strike \\
Total Profits if you pay for shipping, insurance, and damages (assume that \\
$\quad$ the(lesser technique is used), and there is no strike \\
Total Profits if you pay for shipping, insurance, and damages (assume that \\
the better technique is used), and there is no strike \\
\hline
\end{tabular}

\section{Contract Negotiation Assignment:}

You and your partner will negotiate a sales contact for purchasing batteries. Complete the following tasks:

1. Get in touch with your partner, and set a time for initially meeting in person. You must meet no later than October 13. 
2. [DO THIS BEFORE MEETING WITH YOUR PARTNER] Write down your own goals for the contract [be clear as to what legal concepts need to be addressed, and what your preferred contract term is regarding those concepts]. Also write down what you think will be your partner's concerns [i.e., how you expect the other side to want the same concepts addressed]. Write down some questions you may want to ask your partner. (To successfully negotiate, you need to learn much about the other side. Teasing out this information through questions, offers, and proposals is part of the art of negotiation. More knowledge about the other side will help you both strategically and cooperatively: remember, you may want to cooperate to increase profits!) Also, complete the table including a first proposed price for the batteries. Finally, consider the implications of the possibility of the strike: if the strike happens, will you be excused from performance of this contract under either impossibility or commercial impracticability?

3. E-mail me, by noon October 10, a list of the key legal topics/concepts you will negotiate over.

4. Negotiate the material terms of the contract (if you can agree on those terms; if you do not agree, both parties will have to draft entire contract documents on their own). These material terms should address all significant issues indicated above. I strongly recommend you to save the negotiation over the price of the batteries for later: you should first work out other terms of your agreement, because these terms will have an impact over what each side will consider a "fair price." One of your objectives should be to get a large profit.

5. Put your agreed terms down in writing and execute (sign) the contract. The written contract should be drafted in language that you and your partner would understand. It is important to use specific legal terms that we use in class. These specific legal terms work well as headings. However, do not use "legalese:" overly complex construction. Sometimes, it helps to read the contract aloud to ensure that both you and your partner understand it.

6. Take notes while negotiating. These notes may be helpful in case there are problems later.

7. Turn in

a) Your negotiated contract.

b) A one-page commentary on your partner. This commentary should describe how well your partner contributed to this contract. You may discuss things such as how well they were prepared, whether they 
took the project seriously, and how much effort they put into it. You may also discuss lessons that you learned from negotiating with your partner.

c) A one-page commentary on how well the final contract meets your objectives. Include a calculation of how much profit you expect to make, including deductions for any expected losses (multiply the probability of these losses times these losses to calculate the expected loss), as well as an explanation of how you might have sacrificed some objective to achieve others (if appropriate). Also, indicate which manufacturing location you are using. This is not a commentary on whether you cooperated with your partner; it is rather an analysis of whether you were able to achieve your objectives through negotiation.

d) When you turn your contract and commentaries in, put your partner commentary in a sealed envelope. If you rán into difficulties with your partner, you may also include the notes you took during negotiations.

Hints:

1. Read the instructions carefully! It is crucial that you understand your competitive situation and the legal issues that arise due to this situation. Your job may depend upon it!

2. Do not directly tell your partner (nor any other seller) your revenue and outside-supplier-cost information. However, this information may be revealed somewhat through exchanged negotiations.

3. Do not put this off to the last minute. Partner schedules can make it difficult to meet sometimes, so try to arrange meeting as soon as possible.

4. Examine the sample contract at the end of chapter 11. However, use it as a reference, but not as a "perfect" contract. Contracts should be adapted for each situation. Again, remember that you should draft your contract with your own words, so that you can understand it. One thing to note about the sample contract is its use of headings to clearly indicate where potential issues are addressed by the contract. However, if you simply use the contract example, you may miss one or more possible issues. There also may be issues in the sample contract that are not relevant for this assignment.

5. Page limit: no longer than 6 pages, 1.5 spaced, 12 point font (for the contract itself). 


\section{Seller's Instructions:}

You are the CEO of a lithium battery manufacturer headquartered in YourState, Libatt. A large electronics company, Honeycrisp, has approached you about supplying batteries for its new portable audio player. These players normally sell for around $\$ 45$. You know that they are looking to purchase 100,000 batteries for their players. You know that they have other costs in producing these players, but you would like to keep as large a share of their sales revenues for yourself. You are preparing to meet with the division head in charge of this new product. You have collected some important information from within your company.

One of the key concerns in lithium battery manufacturing is the possibility that the batteries may catch fire or explode. There have been a number of recalls for lithium batteries for laptops. In 2006, Dell, Apple, Toshiba, and Lenovo recalled lithium laptop batteries due to possible fire or explosions. ${ }^{81}$ More recently, Hewlett-Packard recalled lithium batteries in 2009. ${ }^{82}$ Lithium battery recalls have not been limited to laptop computers either. In August 2010, Apple recalled iPod nanos due to lithium batteries, because they could "overheat and prevent the iPod nano from working and deform it." 83

These problems are caused by small metal particles that sometimes show up in the lithium solution inside a battery cell. When heated significantly, such as during extended use of a battery, these metal particles may cut into the separator between battery cells. This causes a short circuit, which can lead to a fire or explosion ${ }^{84}$

In one of your older facilities in Mexico, you use a manufacturing process that leaves some of these particles in the lithium battery solution. However, in a new facility in China, you have developed an advanced and costly manufacturing method that virtually eliminates these particles, leading to an essentially zero chance of fire or explosion. You have duplicated this technique in another of your facilities in the United States. Below, you will

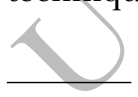

\footnotetext{
${ }^{81}$ See Wilson, supra note 77.

${ }^{82}$ See U.S. Consumer Product Safety Commission, supra note 78

${ }^{83}$ See Etherington supra note 79. See also iPod Fingered in Car Inferno, supra note 79, for a story where an iPod might have led to a fire that "torched" a Saab; see also iPod Nano in airport Trouser Conflagration Horror, supra note 79, for a story where an iPod might have caught someone's pants on fire; see also Japanese Ministry of Economy, Trade and Industry, supra note 79, for a story where an iPod's "battery overheated and partially scorched a tatami mat."

${ }^{84}$ See Wilson, supra note 77.
} 
find a table showing your engineers' calculations of the manufacturing costs of your batteries in each facility; along with their extremely accurate estimates of possible fires, explosions, and monetary damages that would result from these. ${ }^{85}$ If these damages are high, your profits will be significantly lower if you agree to be responsible for paying them. On the other hand, due to the sealed nature of the batteries and a possible distrust of your external markings, your customer may be unable to determine which process you have used.

If all goes well, you can have the batteries delivered within three weeks of the order. However, while you are very pleased with the new manufacturing process you have installed in your new facility in China, you face some possible labor problems there. The workers noticed the improved pay that workers at Honda's factories in China were able to win this past summer by striking ${ }^{86}$ and are considering doing the same on October 23. If they do go on strike [a very good estimate of this happening is a 10 percent chance $(10 \%)$ ], you would expect the strike to last at least one month. This would jeopardize your ability to deliver batteries on schedule. However, you could have the option of using the facility in the United States, which can deliver your batteries within three weeks of taking the order. However, this may not be an attractive option, because your labor costs are significantly higher in the United States. Honeycrisp may have another option that may actually be cheaper than your American facility, but they may want you to pay a penalty if you cannot deliver as promised. Note though, you might be able to negotiate a smaller penalty than the loss you yourself would suffer from using your U.S. facility.

You also have information about your exclusive shipping contractor, Federal Parcel Service (which is the only one you are allowed to contract with). The cost for shipping the batteries without insurance will be $\$ 95,000$. There is a $4 / 2$ percent chance that this shipment would be partially damaged. You have precisely calculated that this damage would cause $\$ 100,000$ worth of damage. Insurance to cover this loss (the shipping company will not pay

${ }^{85}$ All damages will be shown to be the result of manufacturing defects. Manufacturing costs include any fees associated with importing and exporting.

${ }^{86}$ See Takako Iwatani, Yuki Hagiwara, Tian Ying, Liza Lin, Naoko Fujimura, and John Liu, Honda to Resume Production at China Car Factories Tomorrow, Bloomberg (June 10, 2010, 4:31 AM); see also Tian Ying, Yuki Hagiwara, Liza Lin, and Makiko Kitamura, Honda Halts China Plants Amid Parts-Factory Strike, Bloomberg (May 27, 2010, 2:40 AM), http:/ / www.bloomberg.com/news/2010-05-27/honda-shuts-china-car-factories-after-workersat-auto-parts-plant-strike.html http://www.bloomberg.com/news/2010-06-09/honda-to-haltproduction-at-two-guangzhou-plants-on-parts-supplier-strike.html. 
if you do not purchase insurance) will cost an additional $\$ 5,000$. Honeycrisp may use another shipper.

Furthermore, as you can probably tell, you are extremely busy, and do not want to deal with the long delays and cost of litigation. You would prefer using an alternative, if any dispute arose.

Below is a table with some data provided by your company, and some calculations that you should do to help in your negotiation:

Total Manufacturing Cost if use Mexican Facility

Total Manufacturing Cost if use United States Facility

Total Manufacturing Cost if use Chinese Facility

Expected number of overheating incidents if lesser technique used (for 100,000 batteries)

Expected number of overheating incidents if better technique used (for $\quad y$ 100,000 batteries)

Average Expected Damages to Consumers from each Overheating Incident

Total Expected Damages to Consumers if Lesser Technique Used

Proposed Total Price for 100,000 batteries

Total Profits if Use Mexican facility, you are not responsible for costs other than manufacturing ones (no shipping, insurance, damage), and there is no strike

Total Profits if Use Mexican facility, you are responsible for damages to consumers but not shipping nor insurance, and there is no strike

Total Profits if Use Mexican facility, you are responsible for all damages, shipping, and insurance, and there is no strike

Total Profits if Use Chinese facility, you are not responsible for costs other than manufacturing ones (no shipping, insurance, damage), and there is no strike

Total Profits if Use Chinese facility, you are responsible for damages to consumers but not shipping nor insurance, and there is no strike

Total Profits if Use Chinese facility, you are responsible for all damages, shipping, and insurance, and there is no strike

Reduction in profits if you had been planning to use the Chinese Facility, but have to use the United States Facility instead, due to a strike

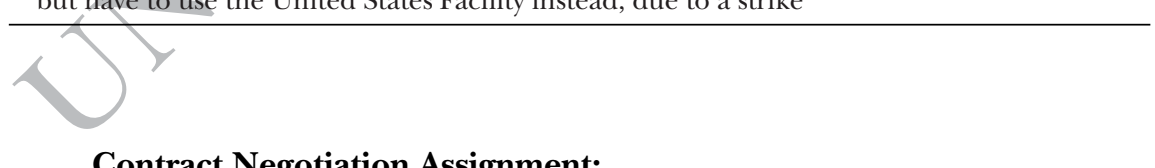

\section{Contract Negotiation Assignment:}

You and your partner will negotiate a sales contact for purchasing batteries. Complete the following tasks:

8. Get in touch with your partner and set a time for initially meeting in person. You must meet no later than October 13.

9. [DO THIS BEFORE MEETING WITH YOUR PARTNER] Write down your own goals for the contract [be clear as to what legal concepts need 
to be addressed and what your preferred contract term is regarding those concepts]. Also write down what you think will be your partner's concerns [i.e., how you expect the other side to want the same concepts addressed]. Write down some questions you may want to ask your partner. (To successfully negotiate, you need to learn much about the other side. Teasing out this information through questions, offers, and proposals is part of the art of negotiation. More knowledge about the other side will help you both strategically and cooperatively: remember, you may want to cooperate to increase profits!) Also, complete the table including a first proposed price for the batteries. Finally, consider the implications of the possibility of the strike: if the strike happens, will you be excused from performance of this contract under either impossibility or commercial impracticability?

10. E-mail me, by [provide date] a list of the key legal topics / concepts you will negotiate over.

11. Negotiate the material terms of the contract (if you can agree on those terms; if you do not agree, both parties will have to draft entire contract documents on their own). These material terms should address all significant issues indicated above. I strongly recommend you to save the negotiation over the price of the batteries for later: you should first work out other terms of your agreement, because these terms will have an impact over what each side will consider a "fair price." One of your objectives should be to get a large profit.

12. Put your agreed terms down in writing and execute (sign) the contract. The written contract should be drafted in language that you and your partner would understand. It is important to use specific legal terms that we use in class. These specific legal terms work well as headings. However, do not use "legalese:" overly complex construction. Sometimes, it helps

to read the contract aloud to ensure that both you and your partner understand it.

13. Take notes while negotiating. These notes may be helpful in case there are problems later.

14. Turn in

a) Your negotiated contract.

b) A one-page commentary on your partner. This commentary should describe how well your partner contributed to this contract. You may discuss things such as how well they were prepared, whether they took the project seriously, and how much effort they put into 
it. You may also discuss lessons that you learned from negotiating with your partner.

c) A one-page commentary on how well the final contract meets your objectives. Include a calculation of how much profit you expect to make, including deductions for any expected losses (multiply the probability of these losses times these losses to calculate the expected loss), as well as an explanation of how you might have sacrificed some objective to achieve others (if appropriate). Also, indicate which manufacturing location you are using. This requirement is not a commentary on whether or not you cooperated with your partner; it is rather an analysis of whether or not you were able to achieve your objectives through negotiation.

d) When you turn your contract and commentaries in, put your partner commentary in a sealed envelope. If you rán into difficulties with your partner, you may also include the notes you took during negotiations.

\section{Hints:}

1. Read the instructions carefully! It is crucial that you understand your competitive situation and the legal issues that arise due to this situation. Your job may depend upon it!

2. Do not directly tell your partner (nor any other buyer) your manufacturing cost information. However, this information may be revealed somewhat through exchanged negotiations.

3. Do not put this off to the last minute. Partner schedules can make it difficult to meet sometimes, so try to arrange meeting as soon as possible.

4. Examine the sample contract at the end of chapter 11 . However, use it as a reference, but not as a "perfect" contract. Contracts should be adapted for each situation. Again, remember that you should draft your contract with your own words, so that you can understand it. One thing to note about the sample contract is its use of headings to clearly indicate where potential issues are addressed by the contract. However, if you simply use the contract example, you may miss one or more possible issues. There also may be issues in the sample contract that are not relevant for this assignment.

5. Page limit: no longer than 6 pages, 1.5 spaced, 12 point font (for the contract itself). 


\section{APPENDix B: InTERnAtional Business Law: Contract Negotiation and Drafting Exercise General Rules \& Instructions}

Buyers are based in the United States and sellers in Germany. Each group is charged with contracting for the purchase and sale of goods. Each paired buyer and seller negotiating group will decide how best to conduct negotiations so that all members of the group fully participate.

Each contract must include all of the basic terms of a contract for the international sale of goods, including delivery terms (using INCOTERMS), payment terms, a clause that addresses issues of performance due to events beyond the control of the parties, and a clause that deals with dispute resolution.

The contract: 200 points (Group portion of the grade) Each paired buyer and seller group will submit one, executed contract for this transaction. Assessment will be based on the following:

1. The group (buyer or seller) that negotiates the most advantageous deal will receive the highest grade. NOTE: so that you understand, this means that the buyer and seller groups negotiating the same contract are likely to receive different grades. Having said this, contracts are about negotiation and building business relationships, not about "winning at any cost."

2. The contracts must demonstrate you understand the basic principles of contracts for the international sale of goods, including how Incoterms are used, currency exchange risk, risk of loss issues, and remedies for breach of contract.

3. Remember that clear writing is important to a clear contract. Therefore, make certain your agreements are well written. It counts.

The Personal notebook/folder 100 points These instructions describe your individual obligations as a participant in the negotiation project. This is a group project that can only succeed with participation by all involved. However, in recognition of the fact that not all members of a group participate equally, your grade for the project will be based upon the group grade, but could be higher or lower than the group grade depending upon the quality of your individual work. The instructor may also assign a matrix for each group to complete ranking the performance of members of the group to assessed with the assessment of individual efforts. 
Each individual is responsible for keeping a personal notebook/folder with details of negotiations process, research, and positions. The following are the most important items to include:

1. Your observations on the negotiating process. DON'T WAIT UNTIL THE END OF THE SEMESTER TO DO THIS. This goes beyond reporting about what was discussed on a given day. After each meeting of your group or negotiation session, write a short piece that analyzes the process. For instance: What are the group dynamics? How does this impact the progress of negotiations? What might be done to change matters? How well are you implementing your negotiation strategy?

2. Your notes and research preparing for meetings and negotiations. This goes beyond class notes or notes from the text (which I don't want to see). These notes include your work preparing for meetings and negotiations, such as your position on which of the INGOTERMS should be selected and why. If you do additional research beyond what is in the text, include the information in your folder.

3. Your notes from negotiating sessions and group meetings. Please note who was present at each meeting in the notes.

Points will be assessed on the quality of individual work you turn in as well as how it reflects the work you did in your group. For example, if you did tremendous research on an important piece for the contract, you'll receive more points than someone whose work was confined to the text. If your personal work indicates you took a leadership role, conducted extensive outside research, or in some other way contributed in a more significant way to the project, your score will reflect that. If your personal work does not meet the standards outlined (for example, you turn in a short, explanatory paragraph for each date only, or your individual work indicates that you did not contribute significantly), your individual grade will reflect that as well.

Final, executed copies of the contract and your individual materials are due no later than [insert date] at the beginning of the class period.

Groups will be assigned meeting times with the instructor during a debriefing period scheduled during the final examination period. Failure to attend the final meeting without approval of the instructor will result in a loss of 10 percent of the points on the individual portion of the contract assignment. 


\section{Buyer's CONFIDENTIAL Negotiating Instructions}

WARNING: THE INFORMATION CONTAINED IN THESE INSTRUCTIONS IS CONFIDENTIAL BUSINESS INFORMATION BEING DISCLOSED TO YOU IN YOUR GAPACITY AS A KEY EMPLOYEe. YOU ARE PROHIBITED FROM DISGLOSING THIS INFORMATION TO ANY OUTSIDE PERSON WITHOUT THE CONSENT OF THE INSTRUCTOR.

1. You work for Potent Potables, Inc., a Delaware corporation with its principle place of business in YourCity, YourState. The company imports and distributes specialty wines, beers, lambics, and other beverages throughout a network of specialty wine shops and liquor stores in Minnesota.

2. Realizing the growing market for flavored malt beverages, ciders, perrys, and lambics in the United States, Potent Potables has been on the lookout for a European product to introduce into the United States. In particular, the company wants something that will compete with a product like Woodpecker hard cider, but more on the higher end of the market like some of the French ciders from Normandy. Statistics from the Global Market Information Database indicate that while cider/perry "does not enjoy a mass following" in the United States, the handcrafted and imported European brands appeal to a particular sector of the market. These are typically packaged in $750 \mathrm{ml}$ bottles and can command high end price points. In addition, total volumes sales are expected to grow by 7 percent over the next several years, although cider/perry will remain a niche market.

3. In October, Marylynn Wolf, Potent Potable's Director of New Products, attended a trade fair in Boston. This is the largest trade show in the United States featuring domestic and imported alcoholic and nonalcoholic beverages. At the show, she discovered a product that might meet Potent Potables' needs: Fuchsrot Apfelwein ${ }^{\circledR}$. The name is pretty awful, but the taste is wonderful. Apfelwein is a traditional German hard cider with a very distinctive flavor. Of the products she sampled, Ms. Wolf feels Fuchsrot's Apfelwein has the best U.S. potential. It is made and sold by Fuchsrot $\mathrm{GmbH}$, a firm headquartered near Frankfurt, Germany. Ms. Wolf met again with Mr. Michael Fuchsrot, the Export Director for Fuchsrot, last week at a big trade show in Frankfurt. There is no doubt that this is a popular beverage, and the company has a long history of exporting German spirits to European and some South American nations.

4. Your job is to negotiate, draft, and execute an advantageous contract for Potent Potables. Despite wanting to expand offerings in interesting 
foreign beverages, Potent Potables has some concerns working with a new vendor based on difficulties with a 2005 contract with a Hungarian company that included late shipments, tainted product that caused illness, and now litigation in Hungarian courts.

5. Despite wanting to play it safe this time, your market research shows there is excellent potential for this kind of product in the United States and for Fuchsrot's product in particular. There is potential for a long-term contract of large proportions. However, your market research also indicates that consumers believe Apfelwein is a sweet apple wine, a product not popular in the United States. There was also a negative reaction to the "Fuchsrot" brand name. Research suggests the product be promoted as a "German hard cider." Of course, the label must include the relevant information, as per U.S. law, as well as the product name and a decent brand name. The contract must include renaming and labeling the product. You have some flexibility on the product packaging and design of the label but absolutely no flexibility on a new name for the product.

6. Ms. Wolf and Mr. Fuchsrot shook hands on a deal for between 12,000 and 18,000 cases of Apfelwein per year. If all goes well, Ms. Wolf expects that amount to triple in the second or third year.

7. After doing your research, you believe that the maximum initial order should be five hundred cases, each case containing twelve, $750 \mathrm{ml}$ bottles of the product. This is the preliminary shipment needed to promote the goods and to see how well Fuchsrot can perform. The initial shipment will be needed for sampling in time for the December 30th holiday party Potent Potables plans each year for customers. If all goes as planned at the spring trade events, you project strong sales, knowing that the fourth quarter will always have the best potential for ciders.

8. There are two important issues you have been instructed to address. First, a number of years ago, the United States imposed 100 percent tariffs on European manufactured goods in response to a trade dispute over imports of U.S. beef grown with hormones. More recently, U.S. steel tariffs imposed by President Bush caused a WTO action, and you know there is always some trade war brewing!!!! Second, in light of your experiences with the Hungarians, you must include a clause that addresses delays, product quality, and the possibility of litigation. You do not want to find yourself returning to Europe to litigate another contract dispute. To help protect against this eventuality, you must include a clause that addresses the law 
to be applied or the forum for dispute settlement and/or the possibility of arbitration, and/or remedies for breach of contract.

\section{Data on Expenses of International Transactions}

International shipping is done by container. A small container is a twenty-foot "box." This is the size typically used for canned and bottled goods. Assume a small international container holds five hundred, twelve-bottle cases [305 mm x $305 \mathrm{~mm}$ x $460 \mathrm{~mm}$ ] of wine, plus space for sampling. A case of wine or cider packaged for export weighs approximately sixteen kilos. Freight rates and service charges are usually per container. (All parties are to assume these prices are correct)

Inland Freight: From Frankfurt to ocean port of Hamburg: $€ 445$ /container (international shipping charges within the European Union are quoted in Euros).

Ocean Freight: From Hamburg to East Coast of the USA: $€ 1400 /$ container if arranged by the seller. $\$ 1,900 /$ container if arranged by the buyer.

Fuel and Security Surcharges: from Trier to a U.S. East Coast seaport: $\$ 995 /$ container.

Customs Duty: You assume there will be customs duty, but aren't sure what it is. You also suspect that there could be other taxes or government requirements, but aren't sure what they might be. There is also a customs clearance/brokerage fee of $\$ 95$ per entry.

Destination Delivery Charges: This is the charge for taking goods from the ship to the container yard where a domestic truck or rail line can take the goods. The charge per container is $\$ 250$ per container, with a minimum charge of $\$ 250$ per shipment.

Inland Freight: From the customs warehouse/container yard on the East Coast to buyer's warehouse in YourCity,YourState: $\$ 650 /$ container.

Local Delivery (destination charge) is $\$ 295 /$ container (which includes the fuel surcharge).

Insurance in transit: Insurance from warehouse to warehouse is .4 percent of the value of the goods (computed in the same manner as calculation of the dutiable value of the goods). In addition, alcohol is considered "dangerous goods" and a special risk commodity, especially since the bottles are glass. Each container is subject to a dangerous goods surcharge of $€ 200$. Note: If you wish to cut the insurance charges any finer than this, presume they will be at the same ratio to total costs as the other freight charges. 
Total transit time for this kind of multimodal transport is approximately twenty days.

Air freight. Air freight is expensive. The door to door rate from Germany (this includes trucking the goods to the Frankfurt International Airport) to Closest International Airport YourState is $€ 2,35$ per kilo plus a fuel charge at $€ 0,95$ per kilo plus a security charge of $€ 0,20$ per kilo. The cost of insurance is the same.

Seller's CONFIDENTIAL Negotiating Instructions

WARNING: THE INFORMATION CONTAINED IN THESE INSTRUGTIONS IS CONFIDENTIAL BUSINESS INFORMATION BEING DISCLOSED TO YOU IN YOUR GAPACITY AS A KEY EMPLOYEE. YOU ARE PROHIBITED FROM DISCLOSING THIS INFORMATION TO ANY OUTSIDE PERSON WITHOUT THE CONSENT OF THE INSTRUGTOR.

1. You work for Fuchsrot $\mathrm{GmbH}$, a manufacturing and export firm headquartered in a suburb of Frankfurt am Main, Germany. For the past seventy years, Fuchsrot has been in the business of manufacturing and distributing German spirits, liquor, and liqueurs and exporting them, primarily to European nations and South American countries.

2. Recently, Fuchsrot decided to expand its market to include the United States. Hard ciders, like Woodchuck and Woodpecker, have been gaining in popularity in the United States as an alternative to beer. Fuchsrot believes it can tap into this market with Fuchsrot Apfelwein. Apfelwein is a kind of hard cider popular in the Frankfurt region, with an alcohol content of between 5 and 6 percent. The name "Fuchsrot" has been a strong trademark in the European and South American markets. In Germany, the strength of the brand means the company can charge a premium for its product.

3. Fuchsrot plans to begin small, but hopes to develop its U.S. operation into a substantial part of its export business. According to the Global Market Information Database, ciders do not have a "mass following" in the United States; the handcrafted and specialty ciders or perrys appeal to a certain sector of the market willing to pay premium prices. Last October, Herr Michael Fuchsrot, Fuchsrot's Director of Export Sales met with Marylynn Wolf, the New Products director from a company called Potent Potables, Inc., when Fuchsrot attended a trade fair in Boston, MA. The directors met again at the big trade fair in Frankfurt am Main last week. Potent 
Potables is a U.S. company headquartered in Egan, MN, wherever that is. The directors discussed the possibility of doing business. The American seemed most interested in Fuchsrot Apfelwein.

4. Fuchsrot sells their award winning Apfelwein to wholesalers and distributors in Europe and South America in cases containing twelve, $750 \mathrm{ml}$ bottles. Typically, Fuchsrot typically requires minimum orders of two thousand cases. Discussions with the American director seemed to go well, and the directors shook hands on a deal for between 12,000 and 18,000 cases. Ideally, this would be a long-term contract. The company has the capacity to double the amount in the next year and possibly triple the amount thereafter (provided the apple season is good and the plant expansion is complete). Oddly, Ms. Wolf for some reason doesn't like the product name. The directors briefly discussed labeling issues and, of course, the bottles would need to be relabeled to comply with U.S. law.

5. It is your job to negotiate the contract with Potent Potables. Fuchsrot's Geschäfrsführung (board of directors) believes that if all goes well, the company can look forward to a long and productive relationship with Potent Potables. Needless to say, they are keen to develop this relationship.

6. It costs Fuchsrot $€ 30,00$ to produce a case of Fuchsrot Apfelwein and $€ 0,95$ per case to package it for export. If the buyer has any special requirements for packaging or labeling, the additional charge is usually $€ 0,25$ per case (if the contract is large enough, Fuchsrot forgoes the labeling set-up fee of $€ 500)$. .

7. You must negotiate, draft, and execute an advantageous contract for Fuchsrot Because at this point you don't anticipate a huge sale, the Geschäfrsführung is requiring that all negotiations be conducted via email and fax, since the amount of profits on smaller transaction won't justify the use of costly international phone calls.

8. There are two important issues you have been instructed to address. First, a number of years ago, the U.S. imposed 100 percent tariffs on European manufactured luxury goods in response to a trade dispute over imports of U.S. beef grown with hormones. And, there appears to be a trade war brewing over protectionist measures the United States instituted over steel. Second, you are required to include some clause that addresses the possibility that the contract might not adequately be performed and the possibility of future litigation (these Americans are a litigious bunch, and their common law, adversarial system seems positively barbaric. There doesn't seem to be an incentive for an American not to file suit). To help 
protect against this eventuality, you must include a clause that addresses the law to be applied or the forum for dispute settlement and/or the possibility of arbitration, and/or remedies for breach of contract.

\section{Data on Expenses of International Transactions}

International shipping is done by container. A small container is a twenty-foot "box." This is the size typically used for canned and bottled goods. Assume a small international container holds five hundred, twelve-bottle cases [305 mm x $305 \mathrm{~mm}$ x $460 \mathrm{~mm}$ ] of wine, plus space for sampling. A case of wine or cider packaged for export weighs approximately sixteen kilos. Freight rates and service charges are usually per container. (All parties are to assume these prices are correct)

Inland Freight: From Frankfurt to ocean port of Hamburg: $€ 445$ /container (international shipping charges within the European Union are quoted in Euros).

Ocean Freight: From Hamburg to East Coast of the USA: $€ 1400 /$ container if arranged by the seller. $\$ 1900 /$ container if arranged by the buyer.

Fuel and Security Surcharges: from Trier to a U.S. East Coast seaport: $\$ 995 /$ container.

Customs Duty: You assume there will be customs duty but aren't sure what it is. You also suspect that there could be other taxes or government requirements but aren't sure what they might be. There is also a customs clearance/brokerage fee of $\$ 95$ per entry.

Destination Delivery Charges: This is the charge for taking goods from the ship to the container yard where a domestic truck or rail line can take the goods. The charge per container is $\$ 250$ per container, with a minimum charge of $\$ 250$ per shipment.

Inland Freight: From the customs warehouse/container yard on the East Coast to buyer's warehouse in YourCity,YourState: $\$ 650 /$ container.

Local Delivery (destination charge) is $\$ 295 /$ container (which includes the fuel surcharge).

Insurance in transit: Insurance from warehouse to warehouse is .4 percent of the value of the goods (computed in the same manner as calculation of the dutiable value of the goods). In addition, alcohol is considered "dangerous goods" and a special risk commodity, especially since the bottles are glass. Each container is subject to a dangerous goods surcharge of $€ 200$. Note: If you wish to cut the insurance charges any finer than this, presume they will be at the same ratio to total costs as the other freight charges. 
Total transit time for this kind of multimodal transport is approximately twenty days.

Air freight. Air freight is expensive. The door to door rate from Germany (this includes trucking the goods to the Frankfurt International Airport) to Closest International Airport YourState is $€ 2,35$ per kilo plus a fuel charge at $€ 0,95$ per kilo plus a security charge of $€ 0,20$ per kilo. The cost of insurance is the same. 


\section{Author Query Form}

\begin{tabular}{ll}
\hline Journal & JLSE \\
Article & jlse12001 \\
\hline
\end{tabular}

Dear Author

During the copy-editing of your paper, the following queries arose. Please respond to these by marking up your proofs with the necessary changes/additions. Please write your answers clearly on the query sheet if there is insufficient space on the page proofs. If returning the proof by fax do not write too close to the paper's edge. Please remember that illegible mark-ups may delay publication.

\begin{tabular}{|l|l|l|}
\hline Query No. & Description & Author Response \\
\hline Q1 & {$[\mathrm{Au}:$ Please check short running head. $]$} & \\
\hline $\mathbf{Q}$ 2 & {$[\mathrm{Au}:$ OK? $]$} & \\
\hline $\mathbf{Q 3}$ & {$[\mathrm{Au}:$ do you mean worst? $]$} & \\
\hline $\mathbf{Q 4}$ & $\begin{array}{l}{[\mathrm{Au}: \text { does this stand for something that should be }} \\
\text { explained? }\end{array}$ & \\
\hline $\mathbf{Q 5}$ & {$[\mathrm{Au}:$ deletion OK? $]$} & \\
\hline $\mathbf{Q 6}$ & {$[\mathrm{Au}:$ is there a URL for this? $]$} & \\
\hline $\mathbf{Q 7}$ & {$[\mathrm{Au}:$ not sure what this URL is referring to. $]$} & \\
\hline $\mathbf{Q 8}$ & {$[\mathrm{Au}:$ sense? $]$} & \\
\hline
\end{tabular}

